\title{
Fuel Cell/Micro-Turbine Combined Cycle
}

\author{
Final Report \\ August 1998 - December 1999 \\ By \\ Larry J. Chaney \\ Mike R. Tharp \\ Tom W. Wolf \\ Tim A. Fuller \\ Joe J. Hartvigson \\ December 1999 \\ DOE Contract：DE-AC26-98FT40454 \\ McDermott Technology, Inc. \\ 1562 Beeson Street \\ Alliance, $\mathrm{OH} 44601$ \\ Northern Research and Engineering Corporation \\ 32 Exeter Street \\ Portsmouth, NH 03801
}




\section{Disclaimer}

This report was prepared as an account of work sponsored by an agency of the United States Government. Neither the United States Government nor any agency thereof, nor any of their employees, nor contractor nor any subcontractor thereunder, makes any warranty, express or implied, or assumes any legal liability or responsibility, for the accuracy, completeness, or usefulness of any information, apparatus, product, or process disclosed, or represents that its use would not infringe privately owned rights. Reference herein to any specific commercial product, process, or service by trade name, trademark, manufacturer, or otherwise does not necessarily constitute or imply its endorsement, recommendation, or favoring by the United States Government or any agency thereof. The views and opinions of authors expressed herein do not necessarily state or reflect those of the United States Government or any agency thereof. 


\begin{abstract}
A wide variety of conceptual design studies have been conducted that describe ultra-high efficiency fossil power plant cycles. The most promising of these ultra-high efficiency cycles incorporate high temperature fuel cells with a gas turbine. Combining fuel cells with a gas turbine increases overall cycle efficiency while reducing per kilowatt emissions. This study has demonstrated that the unique approach taken to combining a fuel cell and gas turbine has both technical and economic merit. The approach used in this study eliminates most of the gas turbine integration problems associated with hybrid fuel cell turbine systems. By using a micro-turbine, and a non-pressurized fuel cell the total system size $(\mathrm{kW})$ and complexity has been reduced substantially from those presented in other studies, while maintaining over $70 \%$ efficiency. The reduced system size can be particularly attractive in the deregulated electrical generation/distribution environment where the market may not demand multi-megawatt central stations systems. The small size also opens up the niche markets to this high efficiency, low emission electrical generation option.
\end{abstract}




\section{Table of Contents}

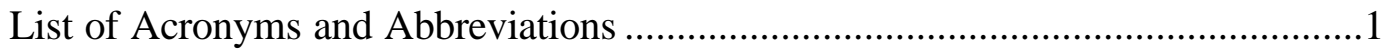

Executive Summary ...............................................................................

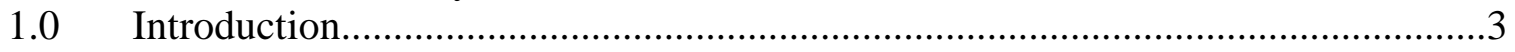

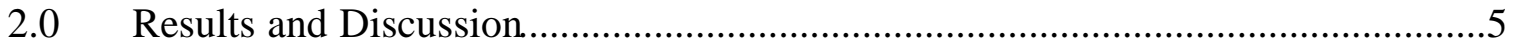

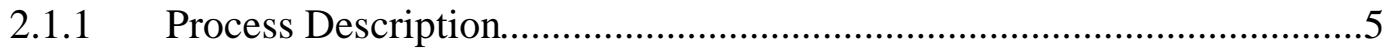

2.1.2 Engine/Fuel Cell Integration Concepts ...............................................10

2.1.3 Design Assumptions......................................................................21

2.1.4 Major Equipment.....................................................................23

2.1.5 Input Data and Heat and Material Balance .......................................28

2.1.6 Modeling Approach and Methodology ..............................................29

2.2 Process/Equipment Uncertainties and Development Requirements .......36

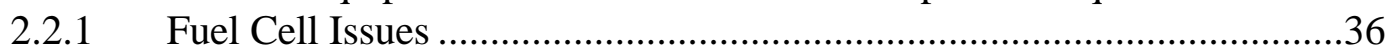

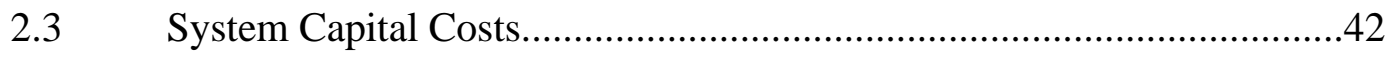

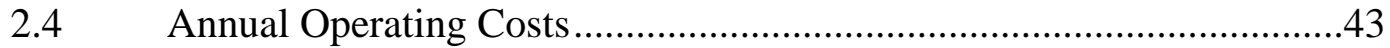

2.5 Opportunities for Improvement and Suggested Work .........................43

2.5.1 Proof of Concept Demonstration - $200 \mathrm{~kW}$ System............................43

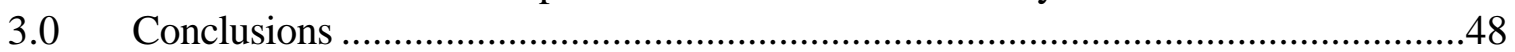

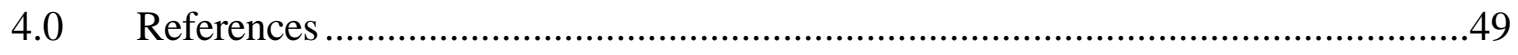

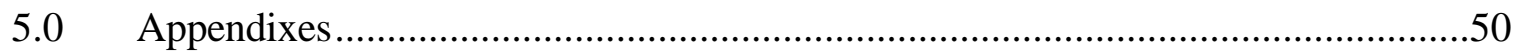




\section{List of Figures}

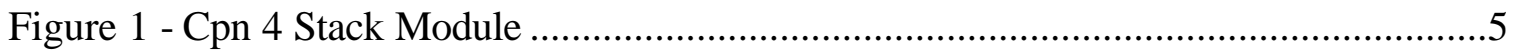

Figure 2 - Fuel Cell Micro Turbine Combined Cycle ........................................................

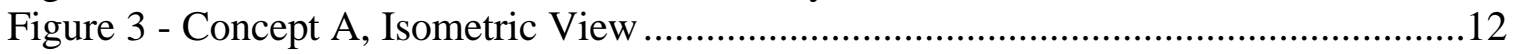

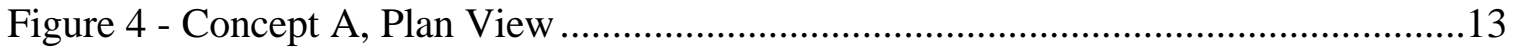

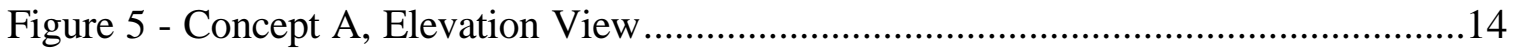

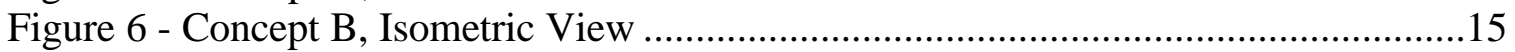

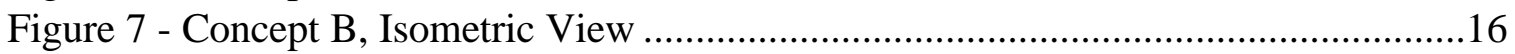

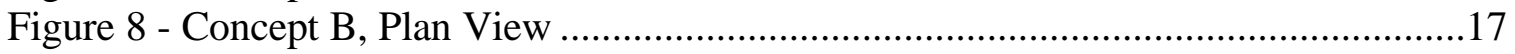

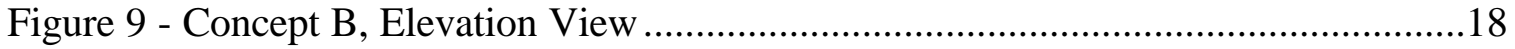

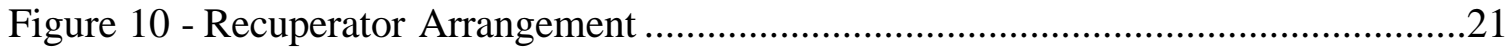

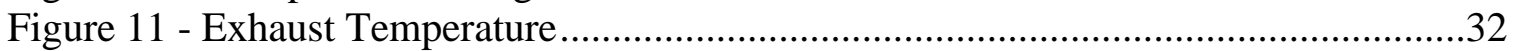

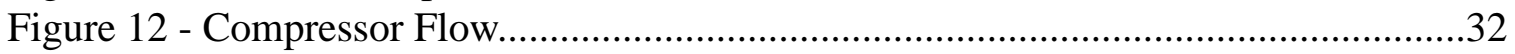

Figure 13 - Engine Electrical Power Output ...........................................................33

Figure 14 - Hot Side Recuperator Inlet Temperature.................................................33

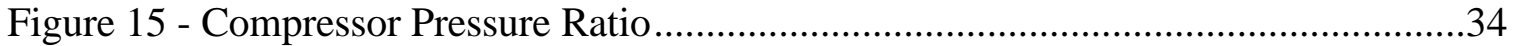

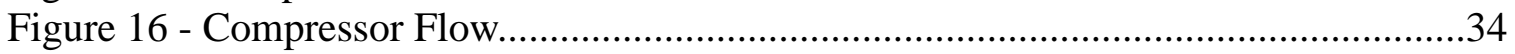

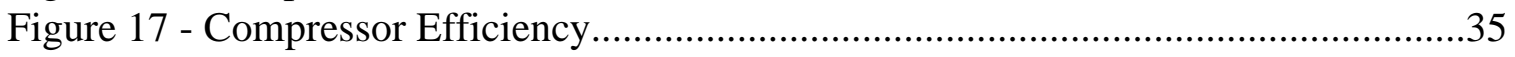

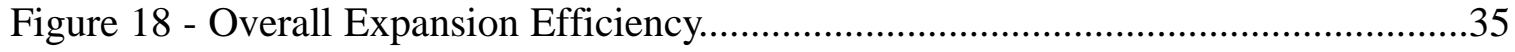

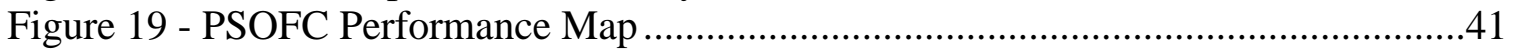

Figure 20 - 180 kW PSOFC/MicroTurbine System......................................................45 


\section{List of Tables}

Table 1 - State Parameters for 700 kW Fuel Cell/Micro-Turbine Combined Cycle............6

Table 2 - Design Parameters for 700 kW Fuel Cell/Micro-Turbine Combined Cycle ........8

Table 3 - Performance Study for $700 \mathrm{~kW}$ Fuel Cell/Micro-Turbine Combined Cycle........8

Table 4 - Component Duty Summary for $700 \mathrm{~kW}$ fuel Cell/Micro-Turbine Combined Cycle.....

Table 5 - Hybrid Recuperator Options ..........................................................................21

Table 6 - Key System Parameters for 700 kW Fuel Cell/Micro-Turbine Combined

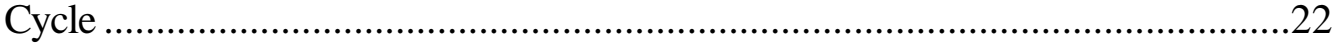

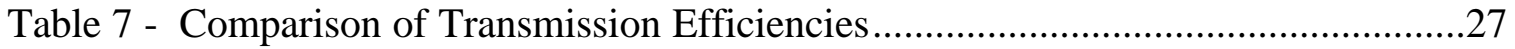

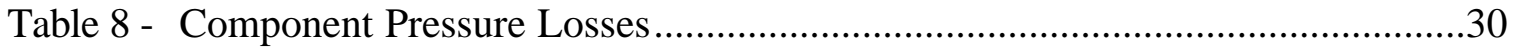

Table 9 - PSOFC/Microturbine Capital Costs .............................................................42

Table 10 - State Parameters for $180 \mathrm{~kW}$ Fuel Cell/Micro-Turbine Combined Cycle .......46

Table 11 - Design Parameters for $180 \mathrm{~kW}$ Fuel Cell/Micro-Turbine Combined Cycle ....46

Table 12 - Performance Summary for 180 kW Fuel Cell/Micro-Turbine Combined Cycle

Table 13 - Component Duty Summary for $180 \mathrm{~kW}$ Fuel Cell/Micro-Turbine Combined Cycle 


\section{List of Acronyms and Abbreviations}

\begin{tabular}{|c|c|}
\hline $\mathrm{AC}$ & Alternating Current \\
\hline AES & Advanced Energy System \\
\hline ASR & Area Specific Resistance $\left(\mathrm{O}^{*} \mathrm{~cm}^{2}\right)$ \\
\hline BOP & Balance of Plant \\
\hline $\mathrm{cfm}$ & Cubic feet per minute \\
\hline $\mathrm{COE}$ & Cost of Electricity \\
\hline $\mathrm{Cpn}^{\mathrm{TM}}$ & Co-planar, n-stack \\
\hline DC & Direct Current \\
\hline DOE & United States Department of Energy \\
\hline GRI & Gas Research Institute \\
\hline HEFPP & High Efficienc y Fossil Power Plant \\
\hline $\mathrm{HHV}$ & Higher Heating Value \\
\hline HT & High Temperature \\
\hline $\mathrm{kW}$ & Kilowatt $(1000 \mathrm{~W})$ \\
\hline $\mathrm{kWe}$ & Kilowatt Electric $(1000 \mathrm{~W})$ \\
\hline LHV & Lower Heating Value \\
\hline MM Btu & Million British Thermal Units \\
\hline MTI & McDermott Technology, Inc. \\
\hline MW & Megawatt $(1,000,000 \mathrm{~W})$ \\
\hline NREC & Northern Research and Engineering \\
\hline ODS & Oxide Dispersion Strengthened \\
\hline OEM & Original Equipment Manufacturer \\
\hline PLC & Programmable Logic Controller \\
\hline PM2000 & Advanced metallic material from Plansee $\mathrm{GmbH}$, Germany \\
\hline PowerWorks ${ }^{\mathrm{TM}}$ & NREC's micro turbine \\
\hline PSOFC & Planar Solid Oxide Fuel Cell \\
\hline SI & SI is an abbreviation for "Le Systeme Internationale d'Unites." \\
\hline \multirow[t]{2}{*}{ SOFCo } & Solid Oxide Fuel Cell Company \\
\hline & $\begin{array}{l}\text { Research and Development Limited Partnership with MTI and } \\
\text { Ceramatec }\end{array}$ \\
\hline TIT & Turbine Inlet Temperature \\
\hline TCE & Coefficient of thermal expansion \\
\hline VHT & High Temperature \\
\hline
\end{tabular}




\section{EXECUTIVE SUMMARY}

A wide variety of conceptual design studies have been conducted that describe ultra-high efficiency fossil power plant cycles. The most promising of these ultra-high efficiency cycles incorporate high temperature fuel cells with a gas turbine. Combining fuel cells with a gas turbine increases overall cycle efficiency while reducing per kilowatt emissions. Fuel cells are widely recognized as one of the most promising family of technologies to meet future power generation requirements. Since fuel cells directly convert fuel and an oxidant into electricity through an electrochemical process, they can achieve operating efficiencies approaching $70 \%$ - nearly twice the efficiency of conventional internal combustion engines. Fuel cells produce very low levels of pollutant emissions $\left(\mathrm{NO}_{\mathrm{x}}, \mathrm{SO}_{\mathrm{x}}\right.$, and $\left.\mathrm{CO}_{2}\right)$. They are also amenable to high-volume production as standardized power modules.

This conceptual study has demonstrated that the unique approach taken to combining a fuel cell and gas turbine has both technical and economic merit. By using a microturbine, and a non-pressurized fuel cell the total system size $(\mathrm{kW})$ has been reduced substantially from those presented in other studies, while maintaining over $70 \%$ efficiency. The approach used in this study eliminates most of the gas turbine integration problems associated with hybrid fuel cell turbine systems. The reduced system size can be particularly attractive in the deregulated electrical generation/distribution environment where the market may not demand multi-megawatt central stations systems. The small size also opens up the niche markets to this high efficiency, low emission electrical generation option.

While the study has discovered no technical obstacles to success, a sub-scale technology demonstration would reduce the risk of performance and enable a full-scale commercial offering. Demonstrating a full size micro-turbine, with a single fuel cell module would prove the concept as well as the major components and balance of plant that would be needed in a full-scale system. 


\section{INTRODUCTION}

Global demands for additional power generation over the next twenty years are about 2 million megawatts, of which 490,000 megawatts are projected to be powered by natural gas (McDermott internal study). As a result of utility deregulation in the U.S., concerns with real and perceived health issues, and capital costs associated with the distribution and transmission of electricity, approximately $30 \%$ of this additional natural gas capacity will consist of modular power plants located close to the user. Fuel cells combined with a micro-turbine are a logical candidate to meet this need. They offer modularity, increased fuel efficiency, and low emissions. Major gas and electric utilities have shown an interest in investing in both fuel cells and micro-turbines (McDermott confidential communications).

A wide variety of conceptual design studies have been conducted that describe ultra-high efficiency fossil power plant cycles. The most promising of these ultra-high efficiency cycles incorporate high temperature fuel cells with a gas turbine. Combining fuel cells with a gas turbine increases overall cycle efficiency while reducing per kilowatt emissions. Fuel cells are widely recognized as one of the most promising family of technologies to meet future power generation requirements. Since fuel cells directly convert fuel and an oxidant into electricity through an electrochemical process, they can achieve operating efficiencies approaching $70 \%$ - nearly twice the efficiency of conventional internal combustion engines. Fuel cells produce very low levels of pollutant emissions $\left(\mathrm{NO}_{\mathrm{x}}, \mathrm{SO}_{\mathrm{x}}\right.$, and $\left.\mathrm{CO}_{2}\right)$. They are also amenable to high-volume production as standardized power modules.

The operating characteristics of a fuel cell/micro-turbine power plant have several important ramifications to the energy service industry. Successful development and commercialization of dispersed fuel cell/micro-turbine power generators will allow:

- Siting flexibility with environmentally friendly energy systems,

- Improved quality of energy services at a reduced cost,

- Ability to rapidly respond to customer needs with modular energy systems,

- Improved utilization of clean natural gas, of which the nation has an abundant domestic supply, and

- Facilitate implementation of clean air policies

This report documents the results of a conceptual technical and economic evaluation of an innovative and unique integration of high temperature fuel cells with a gas turbine. The technical approach described in this program focuses on a planar solid oxide fuel cell (PSOFC) combined with a micro-turbine. PSOFCs have the potential for low cost manufacturability. McDermott Technology Inc. (MTI) has a development program in progress to address various methods of low cost, high volume manufacturing of PSOFCs and stacks. A low cost PSOFC combined with a sub-megawatt gas turbine creates a highly attractive product for the deregulated power market. Other studies have focused on a pressurized fuel cell gas turbine system. This study presents a unique, non- 
pressurized approach to combining PSOFCs with gas turbines. One of the key issues addressed in this study is that of system economics versus efficiency. The objective is to optimize the economic viability associated with the development of PSOFC/microturbine systems while balancing the need for operating efficiency and low emissions. Part of this economic analysis will include an economic analysis of the PSOFC stack operating point.

Based upon previous analyses by MTI and other solid oxide fuel cell related companies, PSOFC/turbine systems have been shown to be capable of operating at efficiencies greater than $70 \%$. Overall, the HEFPP program goals of developing a fuel cell / turbine power plant concept of $20 \mathrm{MW}$ with a net efficiency of greater than $70 \%$ have been met. The goals have been exceeded in that the efficiency target of $70 \%$ has been met at a submegawatt plant size. The smaller plant size gives more flexibility in responding to market demands. 


\section{RESULTS AND DISCUSSION}

\subsection{Fuel Cell / Micro-turbine system analysis}

The analysis of the fuel cell micro turbine combined cycle is described below. The overall process is described first followed by engine fuel cell integration concepts, design assumptions, a description of the major equipment, input data, a heat and material balance and then the modeling approach and methodology.

\subsubsection{Process Description}

This design utilizes a unique combination of fuel cell, turbine and recuperator to achieve a highly efficient cycle in a small, compact market-driven size. The flow and heat requirements of components in the micro-turbine and Solid Oxide Fuel Cell Company (SOFCo) $\mathrm{Cpn}^{\mathrm{TM}}$ (Co-planar, n-stack) fuel cell module have been matched, resulting in a highly integrated package. The micro-turbine is a $70 \mathrm{~kW}$ gas turbine engine under development by Northern Research and Engineering Corporation (NREC). The SOFCo $\mathrm{Cpn}^{\mathrm{TM}}$ concept evolved from recognizing the impact of the balance of plant (BOP) on the economy and efficiency of the total fuel cell system. The design optimizes the total fuel cell system and maximizes the efficiency of the system while simultaneously reducing the number of high temperature components peripheral to the stack. The $\mathrm{Cpn}^{\mathrm{TM}}$ module, shown in Figure 1, consists of a multi-stack arrangement that enhances efficiency through effective thermal coupling of the stacks and the fuel processors. The $\mathrm{Cpn}^{\mathrm{TM}}$ power system is comprised of planar PSOFC stacks, fuel processor components and the BOP equipment. The most significant feature of the $\mathrm{Cpn}^{\mathrm{TM}}$ is the Thermally Integrated PSOFC Module that houses the fuel cell stacks, reformer catalyst tubes, and a spent fuel burner.

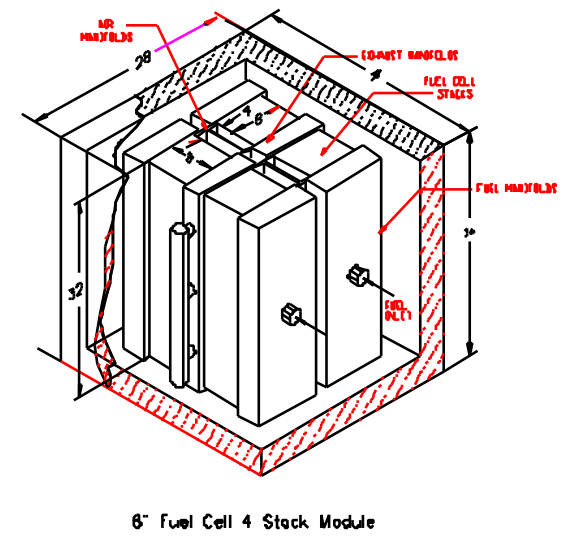

Figure 1: Cpn 4 stack module 
A process schematic for the fuel cell/micro-turbine combined cycle is shown in Figure 2. The state parameters for the system are listed in Table 1, and the design parameters used in the system analysis are listed in Table 2. The air is first compressed in the compressor at a 3:1 pressure ratio. The air is then heated to $1600^{\circ} \mathrm{F}$ in a high temperature recuperator by utilizing exhaust gas from the $\mathrm{Cpn}^{\mathrm{TM}}$ module. The hot, high-pressure air is then

\begin{tabular}{|c|c|c|c|c|}
\hline \multicolumn{5}{|c|}{$\begin{array}{c}\text { Table 1 - State Parameters For } \\
700 \text { kW Fuel Cell/Micro-turbine Combined Cycle }\end{array}$} \\
\hline State Point & $\begin{array}{c}\text { Flow } \\
\mathrm{kg} / \mathrm{s}(\mathrm{lbm} / \mathrm{hr})\end{array}$ & $\begin{array}{c}\text { Temperature } \\
\mathbf{C}(\mathbf{F}) \\
\end{array}$ & $\begin{array}{l}\text { Pressure } \\
\text { kPa (psi) }\end{array}$ & $\begin{array}{c}\text { Enthalpy } \\
\text { J/kg (Btu/lbm) }\end{array}$ \\
\hline 1 & $0.662(5256)$ & $15(59)$ & $101.3(14.7)$ & $-1.35 \mathrm{e} 5(-58.04)$ \\
\hline 2 & 0.622 (5256) & 178 (352) & $304(44.1)$ & $3.11 \mathrm{e} 4$ (13.35) \\
\hline 3 & 0.662 (5256) & 871 (1600) & 300.9 (43.6) & $8.01 \mathrm{e} 5$ (344.37) \\
\hline 4 & 0.662 (5256) & 872 (1600) & 293.5 (42.6) & $8.01 \mathrm{e} 5$ (344.37) \\
\hline 5 & 0.622 (5256) & 639 (1182) & 106.9 (15.5) & 5.31e5 (228.29) \\
\hline 6 & $0.274 \quad(2175.7)$ & 862 (1583) & $104.4(15.1)$ & $7.72 \mathrm{e} 5$ (331.90) \\
\hline 7 & 0.022 (177) & $15(59)$ & 204.7 (29.7) & $-4.74 \mathrm{e} 6(-2037.83)$ \\
\hline 8 & 0.040 (315.4) & $25(77)$ & $120(17.4)$ & $-1.60 \mathrm{e} 7(-6878.76)$ \\
\hline 9 & $0.040(315.4)$ & 108 (226) & $120(17.4)$ & $-1.33 e 7 \quad(-5717.97)$ \\
\hline 10 & $0.062(492.4)$ & 95 (202) & $120(17.4)$ & $-1.02 e 7 \quad(-4385.21)$ \\
\hline 11 & $0.062(492.4)$ & 253 (488) & $120(17.4)$ & $-9.81 e 6 \quad(-4217.54)$ \\
\hline 12 & 0.062 (492.4) & $816(1500)$ & $120(17.4)$ & $-3.81 e 6 \quad(-1638.01)$ \\
\hline 13 & 0.138 (1091.7) & 862 (1583) & $116.8(16.9)$ & $-9.96 e 6 \quad(-4282.03)$ \\
\hline 14 & 0.724 (5748.4) & 913 (1675) & $103.7(15.0)$ & $-1.31 \mathrm{e} 6(-563.20)$ \\
\hline 15 & $0.724(5748.4)$ & 910 (1670) & $103.7(15.0)$ & $-1.32 e 6(-567.50)$ \\
\hline 16 & $0.724(5748.4)$ & 358 (676) & 103.6 (15.0) & $-2.02 e 6 \quad(-868.44)$ \\
\hline 17 & 0.724 (5748.4) & 330 (626) & $102.8(14.9)$ & $-2.06 e 6 \quad(-885.64)$ \\
\hline 18 & $0.724(5748.4)$ & 200 (391) & 102.6 (14.9) & $-2.21 e 6(-950.13)$ \\
\hline
\end{tabular}

expanded through the turbine providing power for the compressor and electrical generation. The turbine produces $68.8 \mathrm{kWe}$ of net electrical power or $9.5 \%$ of the total. The air is then sent to the fuel cell.

Natural gas is mixed with steam that was generated in the steam generator coil, and the mixture is then heated further in the fuel heater. The heated fuel/steam mixture is then sent to the steam reformer. In the steam reformer, the fuel-steam mixture passes over steam reforming catalyst and is processed into hydrogen rich reformate and sent to the fuel cell. The hydrogen and carbon monoxide in the fuel are electrochemically oxidized in the fuel cell producing electrical power. The fuel cell produces $657.6 \mathrm{~kW}$ of electrical power or $90.5 \%$ of the total. The unreacted fuel exiting the fuel cell is burned with the fuel cell cooling air in the fuel cell module enclosure, further boosting the exhaust temperature and providing heat to drive the steam reforming reactions in the steam reformer. The hot gas leaving the $\mathrm{Cpn}^{\mathrm{TM}}$ is then sent to the high temperature recuperator 
where it heats the compressed air, and then is sent to the fuel heater where it heats the fuel and steam mixture. The fuel heater exhaust is used to provide heat to generate the steam that is mixed with the natural gas. The exhaust exits the process at $200^{\circ} \mathrm{C}$. The exhaust could be used to generate low-pressure process steam or space heating in a cogeneration heat exchanger.

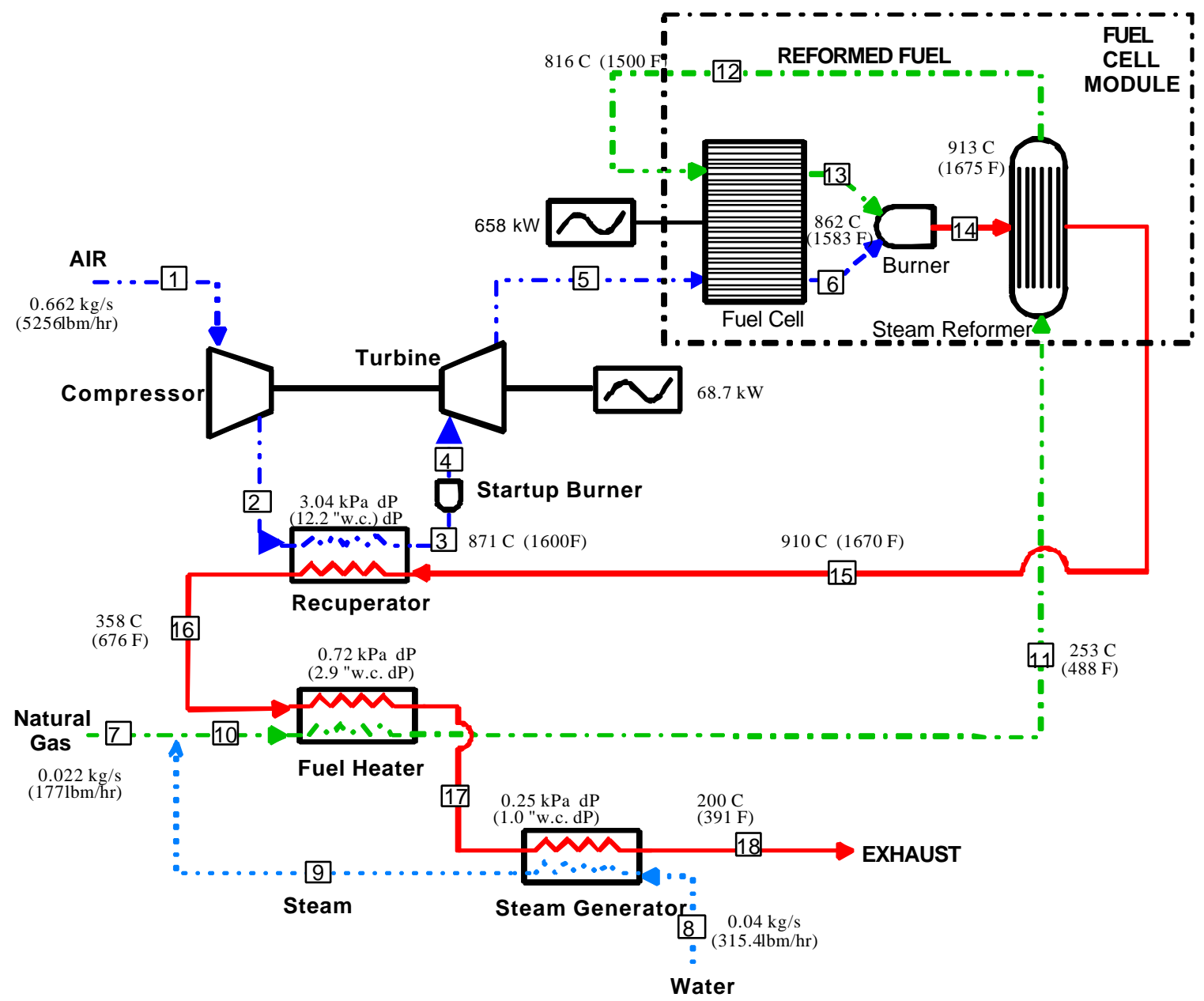

Figure 2: Process Schematic for the Fuel Cell MicroTurbine Combined Cycle 


\begin{tabular}{|l|l|}
\hline \multicolumn{2}{|c|}{ Table 2 - Design Parameters for } \\
\hline \multicolumn{2}{|c|}{$\mathbf{7 0 0} \mathbf{~ k W}$ Fuel Cell/Micro-Turbine Combined Cvcle } \\
\hline \hline Fuel & Natural gas \\
& $0.96 \mathrm{CH}_{4}, 0.02 \mathrm{~N}_{2}, 0.02 \mathrm{CO}_{2}$ \\
& $\mathrm{LHV}=4.81 \mathrm{E} 7 \mathrm{~J} / \mathrm{kg}(20,659 \mathrm{Btu} / \mathrm{lbm})$ \\
Turbine pressure ratio & $3: 1$ \\
Recuperator effectiveness & 0.947 \\
Fuel cell & 15,616 cells \\
Operating voltage & $0.76 \mathrm{~V} /$ cell \\
System heat loss & $0.5 \%$ of heat input \\
Inverter efficiency & $95 \%$ \\
Generator efficiency & $98 \%$ \\
Gear box loss & $5 \%$ \\
\hline
\end{tabular}

The performance of the fuel cell /micro-turbine combined cycle is summarized in Table 3 , and the duties of heat transfer equipment are listed in Table 4. The process produced $726.4 \mathrm{kWe}$ of power at $71.2 \% \mathrm{LHV}$ efficiency. For the HEFPP program requirement of a multi-megawatt system, the process can be considered a module. Twenty-eight modules would produce 18.4 MW. The modular concept is an attractive alternative for the power plant, providing flexibility in turndown, dispatching, and annual maintenance downtime.

\begin{tabular}{|l|l|}
\hline \multicolumn{2}{|c|}{ Table 3 - Performance Summarv for } \\
\hline \multicolumn{2}{|c|}{$700 \mathrm{~kW}$ Fuel Cell/Micro-Turbine Combined Cvcle } \\
\hline \hline Mass flow rate of natural gas & $80.3 \mathrm{~kg} / \mathrm{hr}(177 \mathrm{lbm} / \mathrm{hr})$ \\
Gas flow * LHV & $1,072,897 \mathrm{~W}(3,656,643 \mathrm{Btu} / \mathrm{hr})$ \\
Gross Power & $761 \mathrm{~kW}$ \\
Net Power & $726.4 \mathrm{~kW}$ \\
Efficiency, LHV & 71.2 \\
& \\
Contributions to Power & \\
Fuel cell & $657.6 \mathrm{~kW}$ \\
Turbine & $68.8 \mathrm{~kW}$ \\
Inverter loss & $-34.6 \mathrm{~kW}$ \\
Generator loss & Included in turbine power calculation \\
Gear box loss & Included in turbine power calculation \\
\hline
\end{tabular}




\begin{tabular}{|c|c|}
\hline \multicolumn{2}{|c|}{$\begin{array}{c}\text { Table } 4 \text { - Component Dutv Summarv for } \\
700 \text { kW Fuel Cell/Micro-Turbine Combined Cvcle }\end{array}$} \\
\hline $\begin{array}{l}\text { Component } \\
\text { Fuel heater } \\
\text { Reformer } \\
\text { Recuperator } \\
\text { Spent fuel burner } \\
\text { Steam generator } \\
\end{array}$ & $\begin{array}{l}\text { Duty (kW) } \\
24.2(82,703 \mathrm{Btu} / \mathrm{hr}) \\
372.4(1,270,532 \mathrm{Btu} / \mathrm{hr}) \\
510.2(1,741,011 \mathrm{Btu} / \mathrm{hr}) \\
42.5(144,979 \mathrm{Btu} / \mathrm{hr}) \\
110.2(375,896 \mathrm{Btu} / \mathrm{hr})\end{array}$ \\
\hline
\end{tabular}

Fundamental requirements for the engine operating in a PSOFC system are as follows:

- During the power plant startup cycle, the engine provides hot air for PSOFC preheat and eventual power generation. Through the preheat period ( 20 hours) the engine will operate at a pre-selectable constant turbine inlet temperature, delivering between 45 and $80 \mathrm{kWe} \mathrm{AC}$ power to the grid depending on ambient temperature and the turbine-inlet temperature set point. The cell remains inactive during this phase.

- At the conclusion of the preheat cycle the cell will have reached thermal equilibrium at the engine exhaust temperature of roughly $1200^{\circ} \mathrm{F}$, sufficient for reformer operation. The PSOFC controller then modulates fuel supply to the reformer in order to drive recuperator-inlet temperature toward the $1740^{\circ} \mathrm{F}$ designpoint level. As recuperator preheating occurs fuel supply to the engine combustor is reduced gradually to zero, maintaining turbine-inlet temperature roughly at the $1600^{\circ} \mathrm{F}$ design target. Except for monitoring of safety conditions by the engine controller, engine operation is governed at this point entirely by the PSOFC controller.

- During normal "design-point" operation, running with the combustor off, engine power augments PSOFC electrical output roughly by $10 \%$ while supplying hot air to the cell. The engine controller continues to monitor safety conditions, alerting the PSOFC controller in the event of a fault.

- Under part-load demand with the combustor off, the engine provides reduced electrical output and flow, but generally a higher fraction of PSOFC power than at design conditions.

Additional flexibility in the management of the power plant starting sequence is made possible with the use of the hydraulic drive system fitted with this engine. This proprietary NREC technology relies on a miniature hydraulic turbine mounted on the gasifier shaft, fed by a high-velocity jet of lubricating oil drawn from the engine sump. An attractive feature of this system for the current application is its ability to run for extended periods, delivering 200 to $400 \mathrm{cfm}$ to the PSOFC. This may be applied as a pre-starting or cool-down operating mode. 
During normal power plant operation the combustor is not fired. The engine power and flow under these circumstances depends entirely on turbine-inlet temperature and ambient conditions, the former dependent chiefly on recuperator-inlet temperature. The generator remains synchronized to the utility grid in all conditions. An attribute of this system is that turbine-inlet temperature will not drop substantially during power plant turndown, hence the engine will continue to run at high efficiency. At low PSOFC current density, with flow roughly at the design value, oxidant utilization will be low, boosting PSOFC efficiency.

\subsubsection{Engine/Fuel cell Integration Concepts}

The critical engine/fuel cell integration challenge is the development of a recuperator capable of accepting gas-inlet temperatures in excess of $1740^{\circ} \mathrm{F}$, well beyond the capability of superalloys in this service. The design concepts developed in this study rely on the use of the advanced material PM2000 (Plansee GmbH, Germany), a so-called oxide-dispersion-strengthened (ODS) powdered-metal alloy. Although some questions remain regarding formability of this material in our manufacturing process, provided the problems can be overcome (and we expect that they can) a recuperator very similar in design to that of our current unit will be suitable. This greatly simplifies the job of building the recuperator and of packaging it in our engine.

Despite our optimism that PM2000 can be made to work, we've allowed in our cost projections for a more proven alternative solution in the form of a "hybrid" recuperator. This is the concept put forth in our original proposal, which makes use of a hightemperature tube-shell unit inserted in series with a recuperator similar to our current design. Compared to the single-recuperator approach this concept carries a substantial cost penalty, mostly from the high cost of the tube-shell unit, but also from costs associated with modifying the existing recuperator case and supports. The hybrid approach also carries a performance penalty in the form of additional pressure loss for the same thermodynamic effectiveness.

The hybrid concept has been evaluated to the extent that rough cost projections can be made, but explicit design layouts have been developed only for the single hightemperature recuperator approach. In part this reflects our view as to the superiority of the latter concept, and our optimism that it can be made to work.

The remaining integration challenges are largely associated with ducting hot gases with acceptable pressure and heat losses.

The engine modeled in this study is based on NREC's PowerWorks ${ }^{\mathrm{TM}}$ engine. The PowerWorks ${ }^{\mathrm{TM}}$ engine was originally developed in the early 1980s under GRI sponsorship. It is now in it's fourth generation of development. It incorporates a singlespool gasifier and a low-speed power turbine. A single-stage gear box reduces the 44,000 RPM power turbine to 3600 RPM so that a conventional generator can be used. As a stand-alone machine the PowerWorks engine is tightly packaged to achieve these 
objectives, and significant re-orientation of components is needed to allow for ducting transitions to the fuel cell. The following existing engine systems will require substantial rework:
$\checkmark$ chassis
$\checkmark$ compressor-recuperator duct
$\checkmark$ recuperator inlet plenum/header
$\checkmark$ exhaust plenum
$\checkmark$ lubrication-system piping

Two system layouts (Concepts 'A' and 'B') are shown in Figures 3 through 9. Both concepts make use of a single recuperator core identical in size to the current PowerWorks recuperator, consistent with the use of the advanced high-temperature material mentioned above.

Both concepts are topologically identical, and there is no clear choice with regard to ease of fabrication or cost. Pressure losses will be roughly comparable, the specifications discussed earlier having been used as an approximate basis for pipe sizing in both cases. Concept $\mathrm{A}$ has a small advantage in terms of exposed surface area of hot ducting, but at the expense of slightly more challenging fabrication requirements. Concept A may also pose a bit more difficulty in achieving a flow balance among the modules, and service accessibility looks to be not as good. For these reasons, Concept B has a slight edge, but the choice may ultimately come down to site requirements such as proximity of inlet/exhaust ducting and availability of floor space.

Identical construction is assumed for all fuel cell modules in both concepts. Because of the requirement for vertical stacking of the cells, the gas-inlet aperture on all but the uppermost module in the stack will face its neighbor above. This requires that a spacer be included between each module to provide area for a supply duct. It is assumed that these features, the spacers and supply duct, will be incorporated into the module design. 


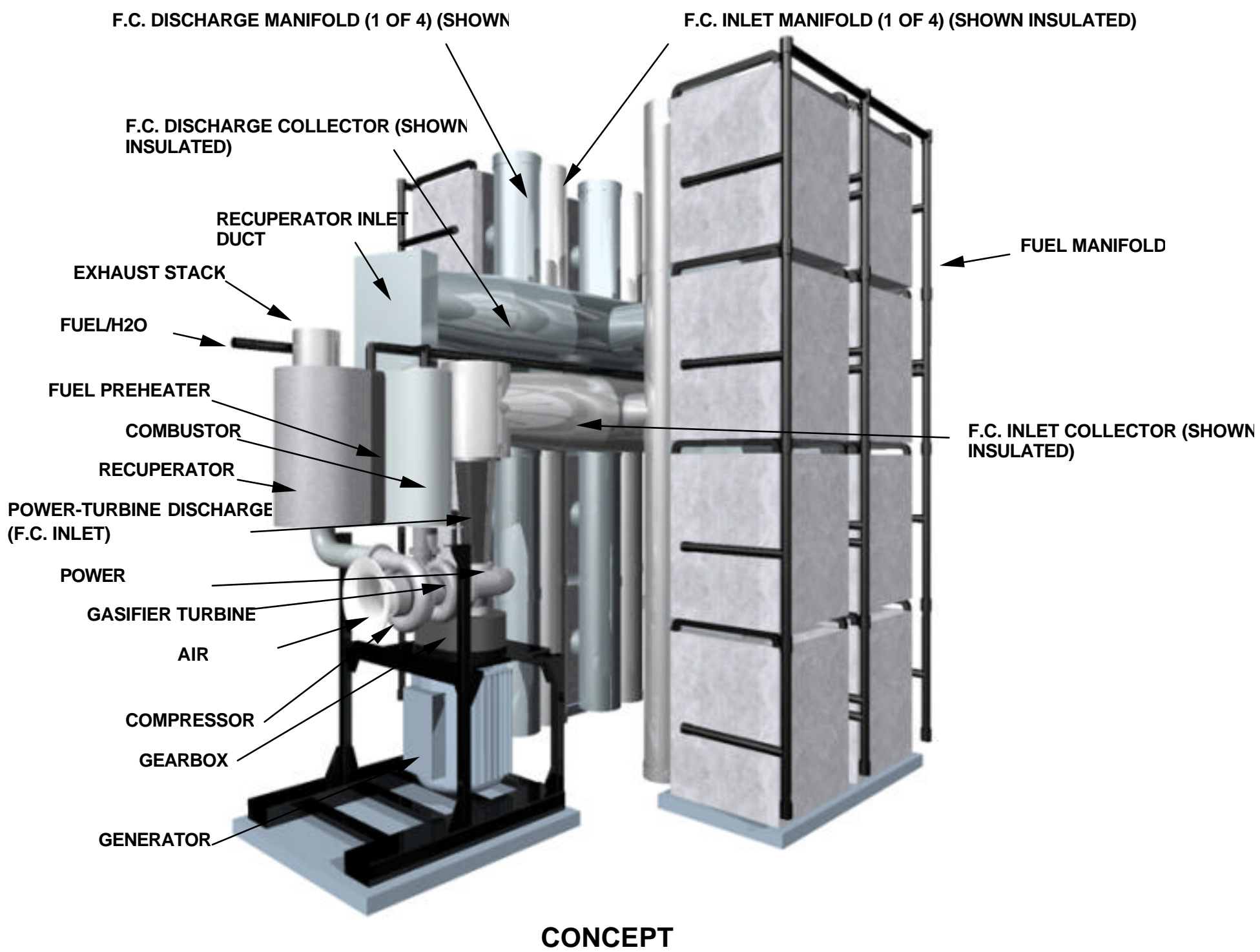

Figure 3 Concept A Isometric View 


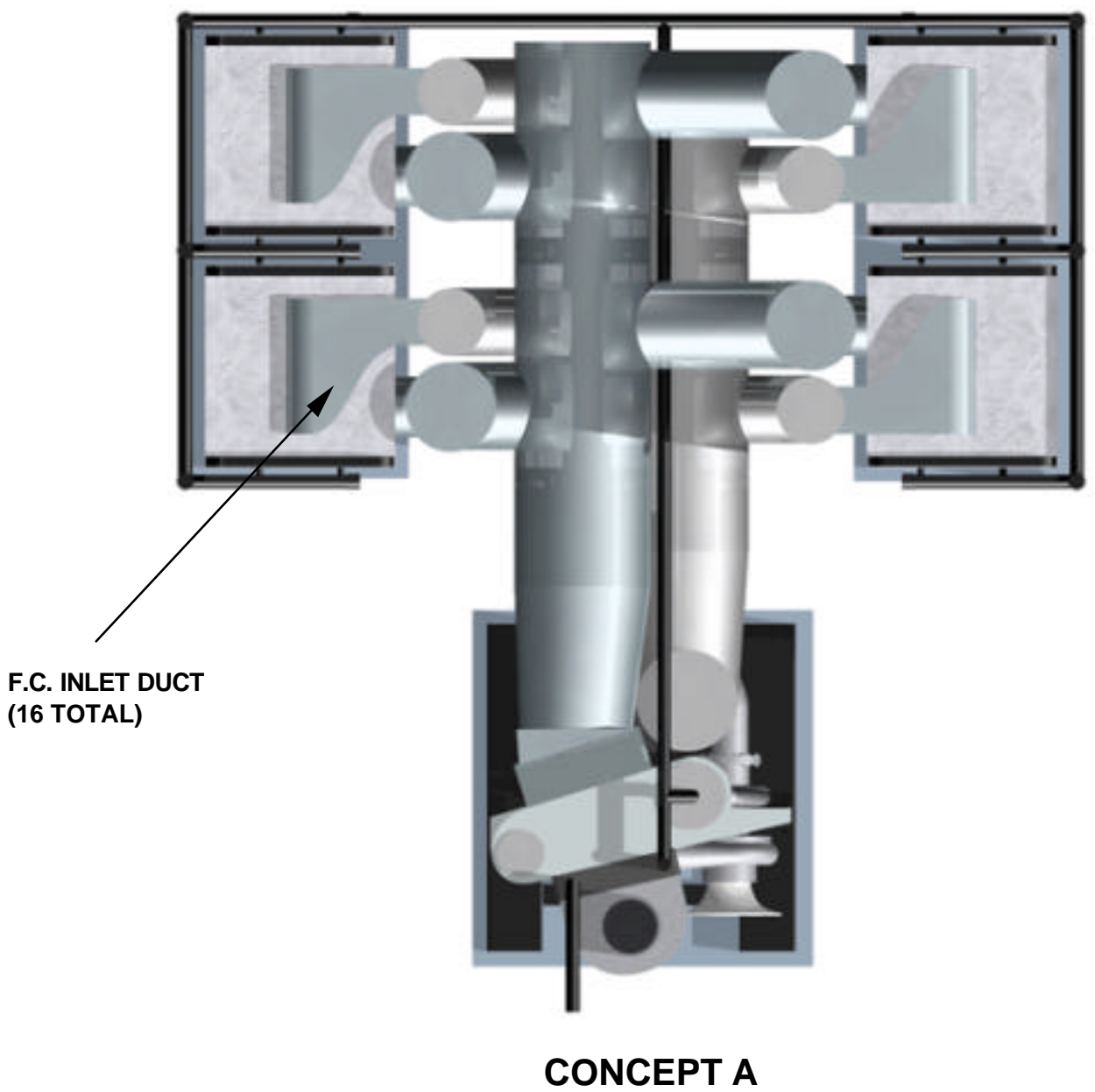

Figure 4 Concept A, Plan View 


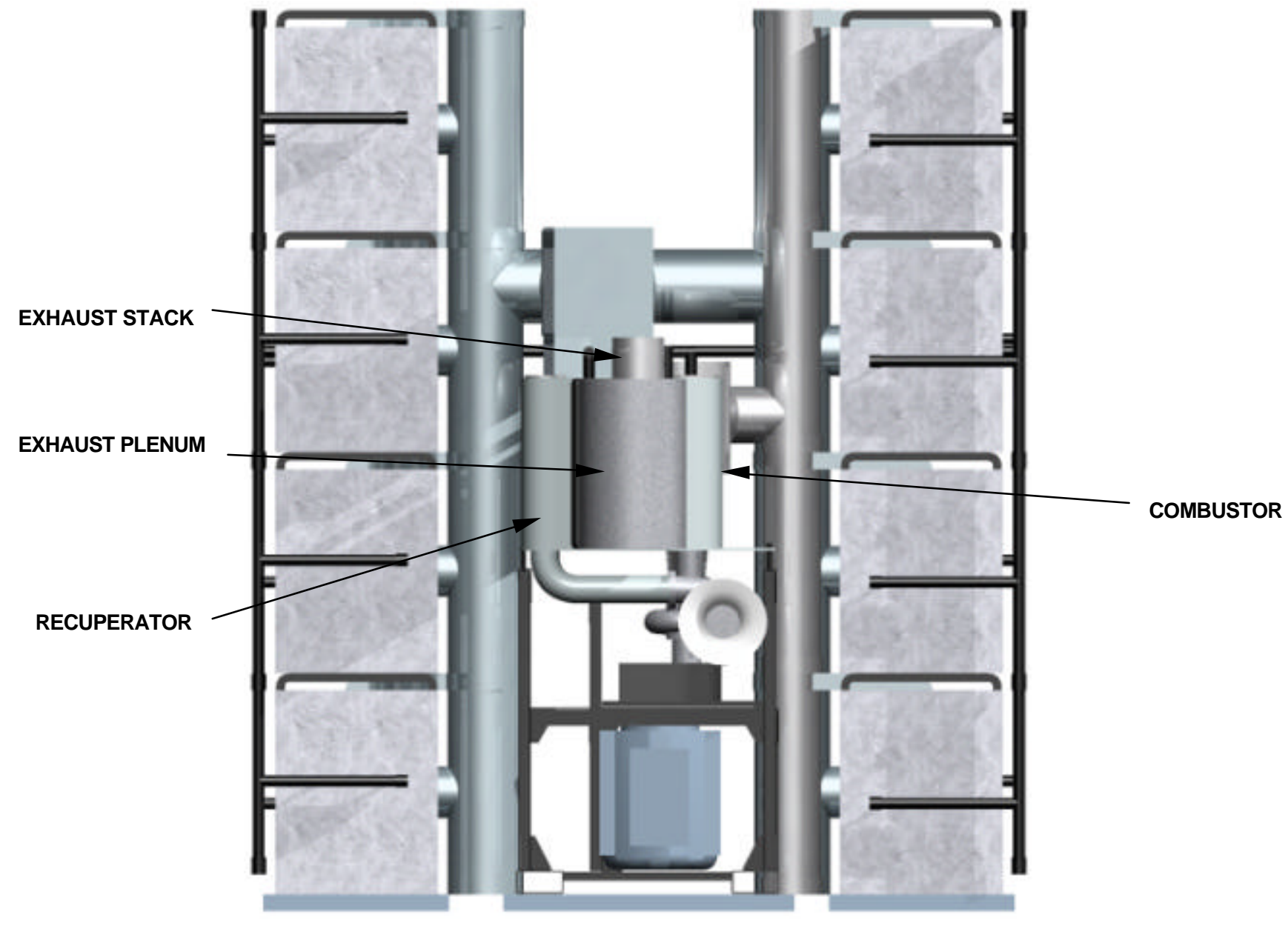

CONCEPT A

Figure 5 Concept A, Elevation View 


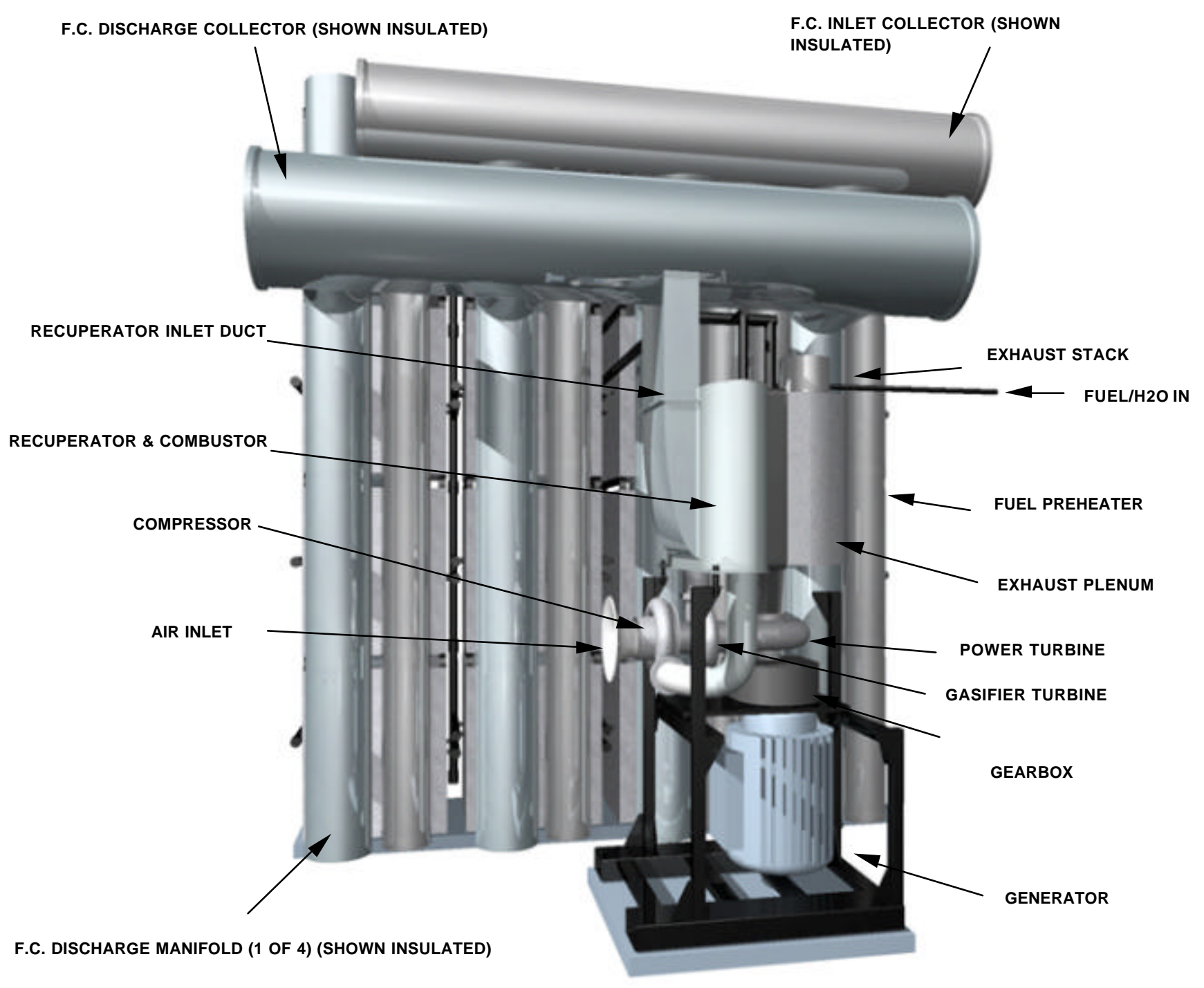

CONCEPT B

Figure 6 Concept B, Isometric View 


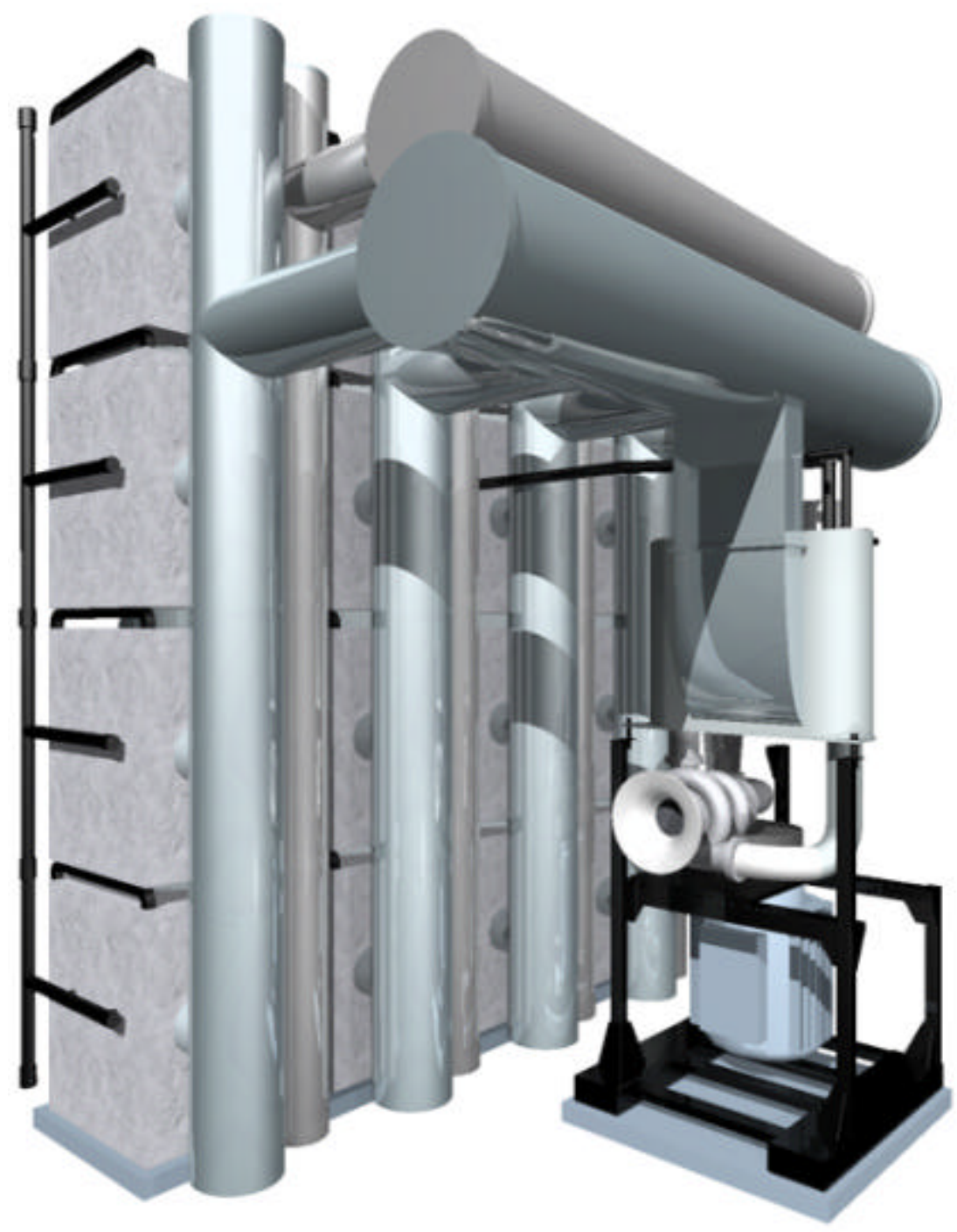

CONCEPT B

Figure 7 Concept B, Isometric View 


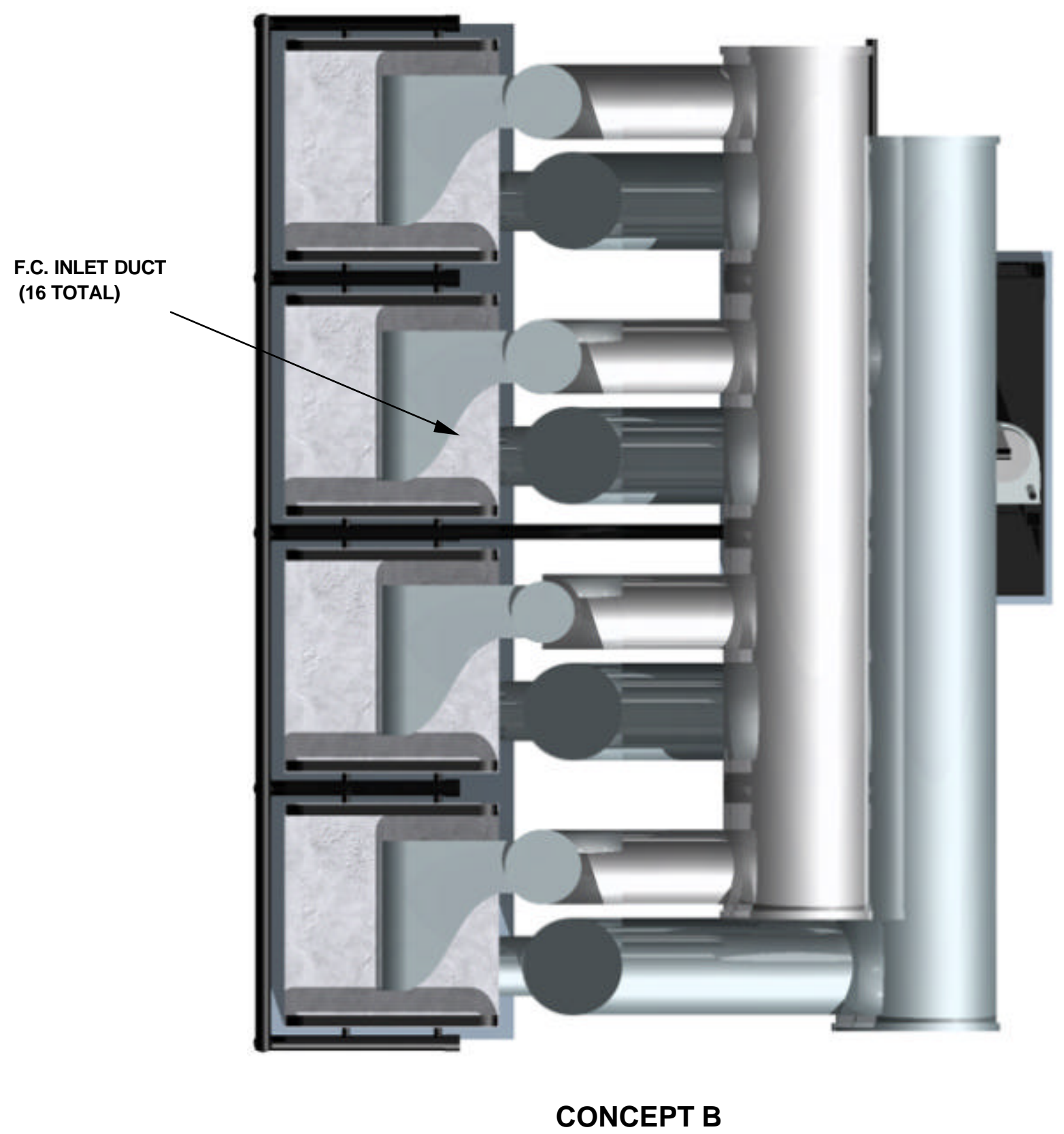

Figure 8 Concept B, Plan View 


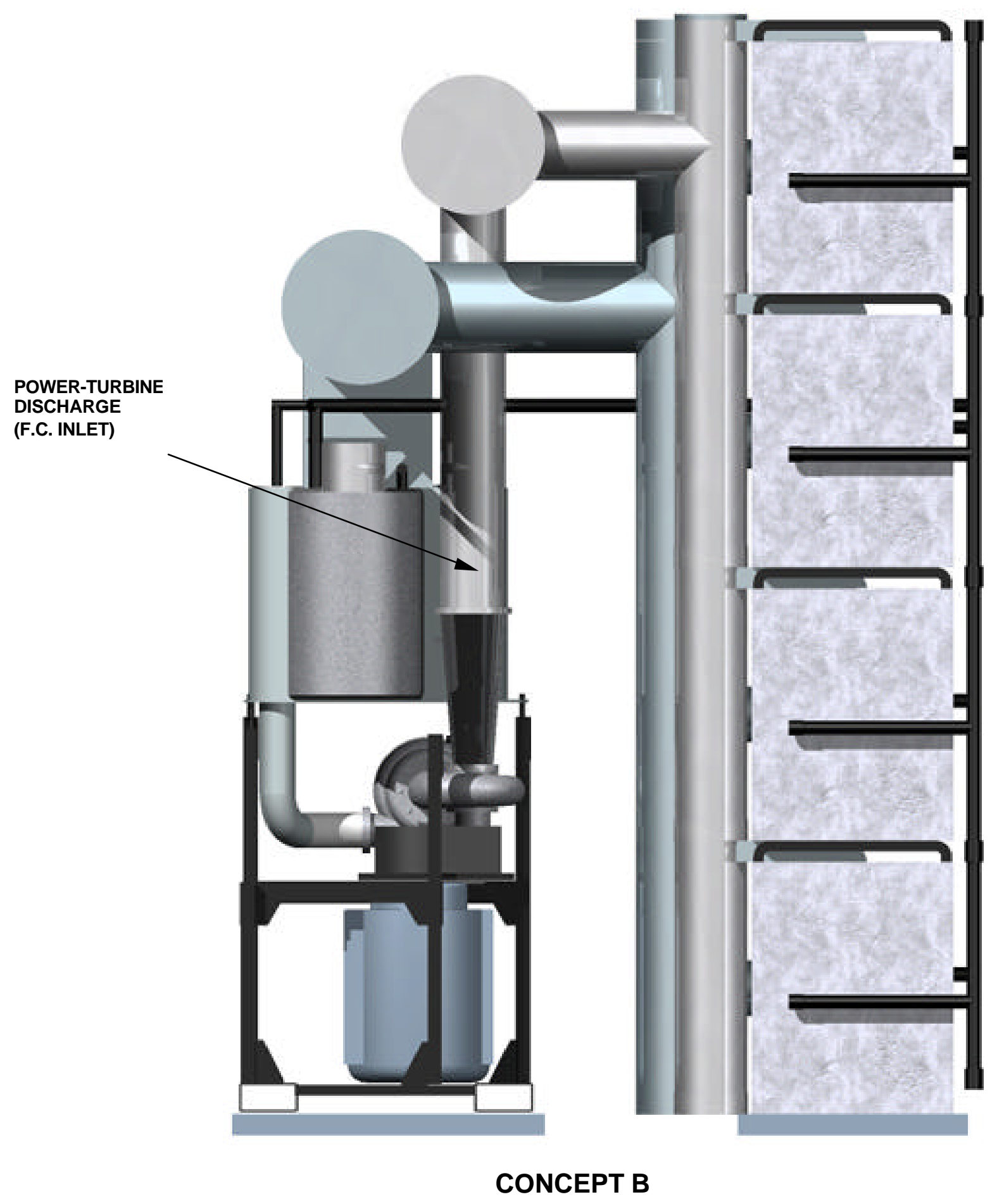

Figure 9 Concept B Elevation View 


\section{Manifold Systems}

The manifold systems comprise large horizontal-running ducts from the engine and vertical ducts at each stack of fuel-cell modules. Ducts have been sized to limit flow velocity to $60 \mathrm{fps}$ (feet per second), consistent with the pressure-loss specifications cited earlier and in an effort to promote uniform flow distribution. Three inches of insulation will limit outer-wall temperatures below $240^{\circ} \mathrm{F}$.

Manifolds would be constructed from light-gauge superalloy sleeves wrapped with insulation and surrounded by heavier-gauge low-grade Stainless Steel. The .035 -inch ${ }^{1}$ thick inner sleeves are segmented, allowing relative sliding to accommodate thermal growth. This choice of wall thickness is based on a 10,000-hr life target based on a .010inch margin. This construction minimizes the weight of expensive materials and avoids use of metal bellows. The strong outer casing also makes for a straightforward approach to supporting heavy piping, although for clarity the structural framework has been omitted from the figures.

\section{Single-Recuperator Approach}

This is the preferred option as discussed earlier, provided that the advanced material PM2000 can be successfully utilized. Strength, oxidation resistance, and thermal conductivity are ample at $1740^{\circ} \mathrm{F}$ based on published data. The material is currently available from Plansee in the appropriate gauge thicknesses.

Successful manufacture of a PM2000 recuperator requires that it be brazable, and that it be amenable to intricate forming in our fin-folding process. Current experience with the manufacture of honeycomb turbine seals proves brazeability, and tentatively indicates that formability will be acceptable. This latter question cannot yet be answered definitively, however. Samples have been sent to a die vendor for further examination of this question.

Cost of PM2000 remains a pressing issue for small quantities, but would be expected to become manageable for production quantities. For preliminary budgeting purposes a speculative cost of $\$ 200$ per lb. was used. Even at this premium price, for prototype development the single-recuperator approach maintains a compelling cost advantage over the tandem concept.

To explore producibility issues and to obtain operational experience, a partial heatexchanger core should be built and rig-tested prior to moving forward with construction of a full unit. This approach was taken during the development phase of our current recuperator, enabling the transition to volume production with low risk. A recuperator core comprising ten cells is envisioned. Experience gained while preparing the test article would likely suggest modifications to the manufacturing process. Testing would

\footnotetext{
${ }^{1}$ The Aerospace Structural Metals Handbook indicates .002-inch loss of material in IN625 after 800 hours in $1,800^{\circ} \mathrm{F}$ air.
} 
include coupon burst-tests to establish strength of the brazed structure, and partial-core burst tests to measure the strength of the heat exchanger. A rig similar to that shown in Figure 10 would be constructed using high-temperature materials, and thermal-cycling and endurance testing carried out. Partial-core testing is envisioned as a separate task and is not budgeted under the current program.

\section{Tandem-Recuperator Approach}

The tandem-recuperator approach represents a compromise that can hopefully be avoided, but investigation remains worthwhile in the event that the single-recuperator strategy is unsuccessful.

The strategy is to make use of a recuperator whose construction would resemble our current design, but likely made from a higher-temperature alloy; this is termed the hightemperature $(\mathrm{HT})$ recuperator in what follows. In series with the HT recuperator is a commercial tube-shell unit capable of withstanding the full $1740^{\circ} \mathrm{F}$ requirement; this is the very-high-temperature (VHT) recuperator. Construction of the HT recuperator would be a very straightforward application of our current manufacturing technology, and carries very low risk. The VHT recuperator is the more serious design challenge.

Ceramics would appear to be an obvious choice for this application in view of their hightemperature capability and low thermal expansion. Tube-shell ceramic heat exchangers are under current development by United Technologies Corporation and CHX Engineering, with units having been successfully tested at temperatures up to $2000^{\circ} \mathrm{F}$. For the proposed application the most compelling disadvantage of these units is their large size compared to a compact plate-fin design, which carries a penalty in terms of the cost of the unit and in terms of integration with the PSOFC power plant.

A cost tradeoff exists between the thermodynamic effectiveness of the two recuperators. For a constant overall effectiveness of the pair, increased effectiveness of the VHT unit reduces the inlet temperature to the HT unit, increasing the size and cost of the former while enabling the latter to be fabricated from lower-cost materials.

It is preferable from an cost perspective to find the temperature limit of the HT heat exchanger, as the VHT unit is expected to dominate the cost. Based on a rough preliminary study of this issue (see table attached), we settled on an effectiveness near $66 \%$ as a rough optimum for the VHT unit. For the HT unit this corresponds to an inlet temperature of $1400^{\circ} \mathrm{F}$ at PSOFC design conditions, although it is unclear at this point whether an IN625 HT heat exchanger will have a satisfactory life at this temperature differential and pressure loading $\left(\Delta \mathrm{T}=1150^{\circ} \mathrm{F}, \Delta \mathrm{p}=38 \mathrm{psi}\right)$. A test program would be needed to confirm acceptability. 


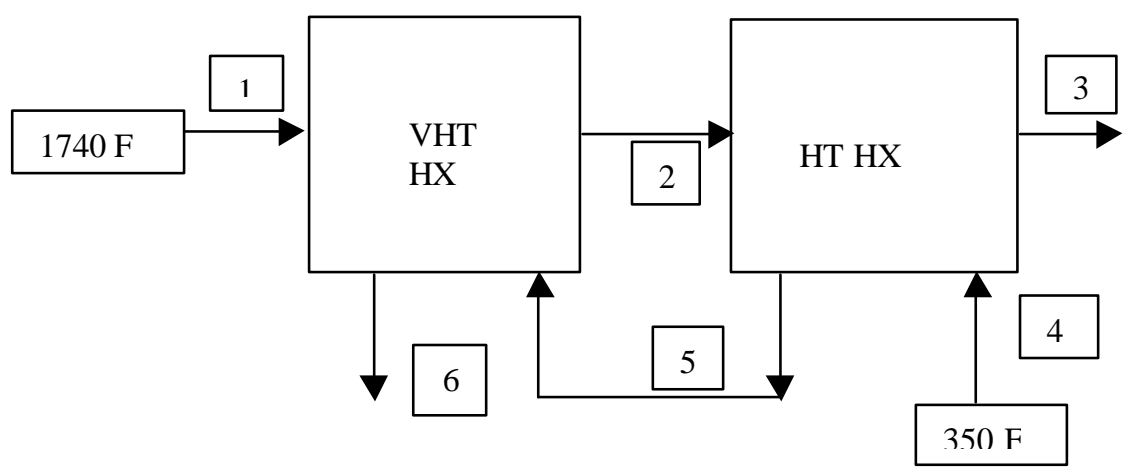

Figure 10 Recuperator Arrangement

\begin{tabular}{|l|c|r|r|r|r|r|r|r|}
\hline \multicolumn{7}{|c|}{ Table 5: Hybrid Recuperator Options } \\
\hline & $\varepsilon_{1}$ & $\varepsilon_{2}$ & $\mathrm{~T} 1, \mathrm{~F}$ & $\mathrm{~T} 2, \mathrm{~F}$ & $\mathrm{~T}, \mathrm{~F}$ & $\mathrm{~T}, \mathrm{~F}$ & $\mathrm{~T} 4, \mathrm{~F}$ & $\mathrm{~T} 5, \mathrm{~F}$ \\
\hline $\begin{array}{l}\text { IN625 HT Recup } \\
\text { (cost basis) }\end{array}$ & $66 \%$ & $93 \%$ & 1,740 & 1,400 & 1,600 & 550 & 350 & 1,327 \\
\hline $\begin{array}{l}\text { 347SS HT Recup } \\
\text { (push) }\end{array}$ & $75 \%$ & $93 \%$ & 1,740 & 1,250 & 1,600 & 521 & 350 & 1,187 \\
\hline $\begin{array}{l}\text { 347SS HT Recup } \\
\text { (safe) }\end{array}$ & $77 \%$ & $93 \%$ & 1,740 & 1,200 & 1,600 & 512 & 350 & 1,141 \\
\hline $\begin{array}{l}\text { IN625 HT Recup } \\
\text { (push) }\end{array}$ & $56 \%$ & $93 \%$ & 1,740 & 1,500 & 1,600 & 569 & 350 & 1,420 \\
\hline
\end{tabular}

\subsubsection{Design Assumptions}

The major system parameters used in this study are shown in Table 6. 


\begin{tabular}{|l|l|}
\hline \multicolumn{1}{|c|}{ Table 6 - Key System Parameters for } \\
\multicolumn{1}{|c|}{ Equipment Assumptions } \\
\hline \multicolumn{1}{|c|}{ KW Fuel Cel/Micro-Turbine Combined Cycle } \\
\hline Number of fuel cell modules & 16 \\
\hline Number of stacks per module & 4 \\
\hline Number of cells per stack & 244 \\
\hline Cell area & $327 \mathrm{~cm}^{2}\left(50.7 \mathrm{in}^{2}\right)$ \\
\hline Cell voltage & $0.76 \mathrm{~V} / \mathrm{cell}^{\circ}$ \\
\hline Cell operating temperature & $862^{\circ} \mathrm{C}\left(1583^{\circ} \mathrm{F}\right)$ \\
\hline Pressure loss, fuel cell + reformer + burner & $3447 \mathrm{~Pa}(0.5 \mathrm{psi})$ \\
\hline Inverter efficiency & $95 \%$ \\
\hline Recuperator effectiveness & 0.947 \\
\hline Turbine pressure ratio & $3: 1$ \\
\hline \multicolumn{1}{|c|}{ Process Engineering Assumptions } \\
\hline LHV of fuel & $4.81 \mathrm{E} 7 \mathrm{~J} / \mathrm{kg}(20,659 \mathrm{Btu} / \mathrm{lbm})$ \\
\hline Heat loss from system & $0.5 \%$ of heat input \\
\hline Water flow & 1.7 steam/carbon mole ratio \\
\hline NOx emissions & Less than 1 ppm \\
\hline
\end{tabular}

The natural gas used in this study was specified by the DOE and is typical of a mid-range heating value gas delivered in the United States.

We assumed that thermal losses from the process are equal to $0.5 \%$ of the heat input. This is a reasonable assumption given the temperatures and sizes of equipment involved in the process. This assumption is also consistent with experience on similarly sized processes.

An inverter to convert $\mathrm{DC}$ to $60 \mathrm{~Hz} \mathrm{AC}$ voltage is a key component for any fuel cell power plant. Development of an inverter is not envisioned to be part of this program. Currently, inverters with $95 \%$ inverter efficiency are commercially available, and this was the assumed efficiency used in this study. 


\subsubsection{Major Equipment}

Fuel Cell Module

SOFCo's CPn ${ }^{\mathrm{TM}}$ module design provided the basis for the fuel cell module used in this power plant. The modified $\mathrm{CPn}^{\mathrm{TM}}$ concept used in this module design, thermally integrates the PSOFC stacks and the methane steam reformer, as well as the air and fuel manifolds. The module was scaled to $43 \mathrm{~kW}$ and a preliminary layout was developed. During this design effort the specifications of the burner that utilized fuel cell exhaust were revised and the spent fuel burner was eliminated. The spent fuel is now burned in the enclosure. The burner specification task in the program plan was revised. The burner specified in this program task was shifted to the micro-turbine startup combustor. The catalytic steam reformer was sized using commercially available catalyst, assumed to be Haldor-Topsoe R67R or equivalent. The methane steam reformer in an integral component of the fuel cell module, and thermally, is highly coupled to the fuel cell stacks. The catalyst loading of the steam reformer was sized conservatively at $600 / \mathrm{hr}$ gas space velocity.

Note that on the process schematic the desulfurizer was not shown. The desulfurizer was not modeled in the simulation as this is a mature, stable technology. However the desulfurizer was sized. A desulfurizer sized for a five year life of the sorbent would be a vessel $15.25 \mathrm{~cm}$ (6.0 in.) in diameter and $122 \mathrm{~cm}$ (48.0 in.) long. The sorbent was assumed to be Haldor-Topsoe HTZ-3 or equivalent. After 5 years the sorbent is easily changed and the spent sorbent is non-hazardous and needs no special disposal.

\section{Engine}

The PowerWorks ${ }^{\mathrm{TM}}$ engine incorporates the most widely accepted industrial gas turbine mechanical configuration, known commonly as a free-power-turbine design. The gasifier turbo-compressor section delivers hot pressurized combustion gas to the power turbine, which provides a versatile and mechanically simple power-take-off. The mechanical design is such that the power turbine is overhung from its bearing core and thermally isolated from the load. Thermal isolation of the hot sections from the load is fundamental to maintaining a stable rotating assembly, and minimizes performance losses.

In addition to simplifying the load connection, the twin turbines split the cycle work, thus operating at roughly half the stress of a single turbine assigned to the same duty. The gasifier section is formed from a low cost turbocharger. NREC customizes the aerodynamics and ruggedizes the turbine housings.

The turbomachine utilizes proven pressurized-oil floating-ring journal bearings. These bearings are the most reliable used in the turbomachinery field, often compiling hundreds of thousands of trouble free hours of operation in a gas turbine engine. Large dimensional clearances on a thick oil film make them exceptionally durable and tolerant to erosion from contaminants. In geared applications, an angular contact ball bearing is 
used on the load end of the shaft. The B1 life of all bearings in the PowerWorks ${ }^{\mathrm{TM}}$ turbomachinery, as defined from a large industry data base, exceeds 100,000 hours. Recuperator

NREC's recuperator has been designed for the challenging "micro-turbine" product specifications. Low cost and exceptional durability are its primary features. The design has been thoroughly tested over thousands of hours of extreme cycling. No other commercial recuperator could stand up to the high pressure and rapid thermal cycling that has been prescribed by our US Navy qualification program. NREC began production of the recuperator in our newly capitalized facility in Portsmouth, NH in April,1997.

Two alternative recuperator strategies are proposed in connection with the current program. In both cases the design is substantially identical to that of our production unit, but higher-temperature materials are substituted. These strategies are discussed in a separate section of this report.

\section{Combustor}

The combustor proposed for the integrated PSOFC package would be a modification of the standard patented PowerWorks ${ }^{\mathrm{TM}}$ design, originally developed in 1990 in collaboration with SoCal Gas. It has consistently demonstrated NOx levels below 9ppmv, with exceptionally good turndown stability and proven durability.

Departure from the standard PowerWorks ${ }^{\mathrm{TM}}$ design is needed to limit combustor pressure loss during unfired operation. Combustor inlet temperature under these conditions will be in the vicinity of $1600 \mathrm{~F}$, whereas the current running condition is around $1200 \mathrm{~F}$. The design change needed to accommodate this difference is straightforward, and is roughly a matter of increasing the effective flow area of the combustor.

\section{Generator/gearbox}

The standard PowerWorks ${ }^{\mathrm{TM}}$ package incorporates a single-stage helical gear set to transfer power from the turbine to the 3600 RPM generator. The low-torque, highsliding-velocity results in exceptional design-life margins. At the conditions specified for the PSOFC, the gear and bearing life exceed one million hours.

A commercial 2-pole 3600 RPM induction generator is standard with the PowerWorks ${ }^{\mathrm{TM}}$ package, and for a production version of the proposed system would be the probable choice. The manufacturer predicts a B10 life of 160,000 hours for normal service. The generator has been conservatively selected and operates in a cool, clean, low-vibration environment. For cold weather and extended peaking-power operation, a higher power rated generator can be provided. An optional synchronous generator can also be substituted for grid-isolated operation, as proposed in connection with the current experimental program. 


\section{Controls and starting}

The PowerWorks ${ }^{\mathrm{TM}}$ engine is currently controlled by an industrial programmable logic controller (PLC) while undergoing laboratory testing. The production version of the product will incorporate Ingersoll-Rand's standard Intellesys ${ }^{\mathrm{TM}}$ micro-processor based controller. The PLC is well suited for the initial PSOFC/GT demonstration unit because of its versatility, allowing basic engine control and safety functions to be integrated readily with those of the PSOFC. During start-up, the controller monitors the powerturbine speed as it accelerates toward synchronous operation, at which point the induction generator is latched to the grid and remains at a fixed $3600 \mathrm{rpm}$. During the PSOFC preheat period, the controller governs engine fuel throttle to maintain the prescribed turbine-inlet temperature set-point.

The engine is started by activating the hydraulic starter, a miniature turbine located between the bearings of the gasifier turbocompressor. This can drive the gasifier to modest speeds for indefinite periods without harming the engine or components.

Depending upon the capacity and set-point of the PowerWorks oil pump, the engine centrifugal compressor delivers 15 to $25 \%$ of the rated flow through the system. After starting (igniting) the engine the oil pump drops back to a low speed-setting as it continues to feed lubricant to the bearings.

Natural gas boosting system

NREC provides a special-duty natural-gas booster package built from a mature IngersollRand oil-free compressor product. It is capable of delivering between 10 and $60 \mathrm{icfm}$ to about $60 \mathrm{icfm}$ (inlet cubic feet per minute). For the proposed application the booster would operate at roughly $25 \mathrm{icfm}$ with a parasitic electrical power consumption of about $2 \mathrm{~kW}$.

Alternative Turbomachinery concepts evaluated

Over the course of the PowerWorks ${ }^{\mathrm{TM}}$ development, trades were evaluated in a number of areas relevant to this project. Significant results and conclusions are discussed in the following paragraphs.

Single-shaft vs. twin-shaft turbomachines

Several attempts have been made to integrate a shaft-speed alternator into the single spool turbo-compressor. Locating the alternator between the bearings with an over-hung turbine and compressor is a common mechanical arrangement, implemented in the AES $50 \mathrm{kWe}$ cogeneration project by Allied Signal (1984-1990) and the Chrysler Patriot by SatCon and NREC (1994-1996). One of the attractions of this arrangement is that it affords a clear aerodynamic path for the inlet and exit flows from a radial turbine and centrifugal compressor. The primary challenge in this design is the cooling system 
associated with the alternator and bearings. The high power-density of the high-speed alternator, with combined electrical and windage losses of nominally $10 \%$, coupled with the close proximity of the turbine section, demands large quantities of liquid cooling. Neither of the two programs cited above resolved the interrelated cooling, stress, and dynamics issues associated with this configuration.

Relocation of the high-speed alternator to the inlet of the compressor avoids many of the problems encountered with the alternator cooling. The disadvantages are increased bearing-system cost, and performance losses. To support the dynamic system, usually three rather than two high-speed bearings are required. This results in tight-tolerance manufacturing methods typical of the aerospace industry. Avoidance of this manufacturing operation is a primary distinction between high cost aerospace turbocompressors and the common industrial turbocharger.

The performance compromises associated with the compressor-end shaft speed alternators stem from heating of compressor-inlet air, inlet pressure drop, and mechanical losses. The Brayton cycle's sensitivity to temperature ratio makes the first effect predominant. The inlet-cooled alternator and bearings would liberate approximately $10 \%$ to $12 \%$ of the shaft power as electrical and windage losses, raising inlet temperature by an amount sufficient to decrease engine efficiency by 1 to 2 percentage points and power by 4 to $8 \%$, depending on operating conditions. Combined with an inlet pressure drop estimated at roughly $1 \%$, the net effect would be to reduce power by $7 \%$ and efficiency by $6 \%$ at nominal PSOFC design conditions.

Alternator selection: high-speed permanent magnetic vs. commercial low-speed generator

The versatile PowerWorks ${ }^{\mathrm{TM}}$ power take-off has been designed to adapt to either highspeed or $3600 \mathrm{rpm}$ loads. The power-take-off shaft is in a cool region and supported by rugged conventional bearings. Either a shaft-speed permanent magnet alternator or a low-speed generator are adaptable to the PowerWorks ${ }^{\mathrm{TM}}$ engine. For high quality AC applications, the standard 2-pole commercial generator is the preferred choice. Lower cost and proven reliability are the dominating factors in grid-compatible AC power generation applications.

Compared to the rare-earth magnet alternators, the PowerWorks ${ }^{\mathrm{TM}}$ system with lowspeed generator is more efficient on a total system basis. Table 7 compares electrical conversion efficiencies for the candidates. 


\begin{tabular}{lll}
\multicolumn{2}{c}{ Table 7 Comparison of Transmission Efficiencies } \\
Component, efficiency & Shaft-speed alternator & PowerWorks \\
bearings, turbine & $98 \%$ & $98 \%$ \\
alternator/generator, electrical & $95 \%$ & $95 \%$ (including bearings) \\
bearings, alt/gen & $98 \%$ & --- \\
alt/gen windage & $96 \%$ & $>99 \%$ \\
inverter/rectifier & $95 \%$ & \\
gearbox, mesh & & $>98.5 \%$ \\
Total conversion efficiency & $83 \%$ & $>90 \%$
\end{tabular}

Note: In the PowerWorks ${ }^{\mathrm{TM}}$ drive train, there are only two bearings on the turbine shaft, and two supplied with the generator. There are no other bearings specifically associated with the "gearbox". PowerWorks ${ }^{\mathrm{TM}}$ generator manufacturer's data shows combined efficiency (electrical, bearings, windage, etc.) of $94.9 \%$ at $25 \mathrm{kWe}, 95.4 \%$ at $50 \mathrm{~kW}$-e, $94.7 \%$ at $75 \mathrm{kWe}$.

Either an induction generator or a synchronous generator may be used in the PowerWorks ${ }^{\mathrm{TM}}$ package. The induction generator has the advantage of low cost and the broadest utility acceptance. Ingersoll-Rand, one of the largest induction motor/generator purchasers, receives the competitive OEM price of about 20 to $25 \$ / \mathrm{kWe}$ for this size induction motor. Efficiencies greater than $94 \%$ are guaranteed by the suppliers. Equally importantly, the reliability of this type of generator is well known and excellent. Data supporting a statistical mean time between forced outage of 318,300 hours has been compiled by GRI and Ingersoll-Rand from the various manufacturers.

The synchronous generator is mechanically connected to the PowerWorks ${ }^{\mathrm{TM}}$ package in exactly the same manner as the induction generator. Synchronous generators have the added benefit of stand-alone capability and on-site power-factor correction. This can be a compelling economic advantage to industry users who pay premiums to their local utility for substandard power factors. Coupled with an inverter system, required for the PSOFC, the synchronous generator could provide vital power-factor correction. The synchronous generator is also the preferred choice when "block-loading" occurs, a common standalone specification. In the integrated PSOFC application, this feature of the synchronous generator could improve the system response to abrupt load changes.

As a future product enhancement, a direct drive such as an air conditioning chiller or some other industrial load might be considered with the PowerWorks ${ }^{\mathrm{TM}}$ packaged system. This would further improve overall conversion efficiencies and net system payback.

Bearing selection

Over NREC's 40-year history in the turbomachinery field, many types of gas-turbine engine bearings have been evaluated. For the PowerWorks ${ }^{\mathrm{TM}}$ product, a variety of 
bearing configurations were analyzed including rolling contact, and journals employing air, refrigerant vapor, water, and oil.

Anti-friction rolling contact bearings are the most efficient, provided the DN (diameter $\mathrm{x}$ speed) rating is maintained at appropriate levels. Losses are 1/10th to $1 / 5$ th that of journal bearings. They have been reliably used for many years in gas turbines. With the maturity of a large well-developed statistical data base, the bearing life is accurately predicted. At the design conditions of the PowerWorks ${ }^{\mathrm{TM}}$ power turbine, angular contact ball bearings are the best choice, providing a life in excess of 80,000 hours at the extreme power condition of $105 \mathrm{~kW}$ (cold day).

Air journal bearings, not yet used in the gas turbine field, are best suited for ultra-clean environments within tightly-controlled temperatures. Other than some experimental gas turbines, their experience has been in cool environments on aircraft air-cycle machines. Air journal bearings also have the added limitations of higher windage losses and greater parasitic cooling losses as compared to oil journals. Their tighter tolerance components make these bearings more expensive than most other bearings.

Several types of oil journal bearings are used in the turbomachinery field. The principal attraction is the "zero wear" experienced as metal contact is isolated by a film of lubricant. Pre-lubrication from either the pump or a bladder-type accumulator minimizes starting wear. The floating-sleeve type, selected for the PowerWorks ${ }^{\mathrm{TM}}$, uses a freefloating ring between the static and rotating bearing surfaces. This modern bearing has lower losses than conventional sleeve-type bearings and provides improved stability. These bearings have become the standard on low cost turbochargers, costing only a few dollars to manufacture.

\subsubsection{Input Data and Heat and Material Balance}

We modeled our fuel cell/micro-turbine combined cycle process using the commercially available ASPEN Plus process simulation software package. The process flowsheet shown in Figure 1 along with the design criteria shown in Tables 2 and 5 were used to build the ASPEN simulation. ASPEN does not contain a standard unit operation for solid oxide fuel cells. MTI in collaboration with SOFCo had previously developed a proprietary model based on SOFCo FORTRAN subroutines. The proprietary model was fully integrated into the ASPEN simulation. The physical and thermodynamic property data used in our study came from ASPEN's extensive and widely-recognized property database.

Detailed heat and material balances were performed on the completed process model. For ease of reference, we have summarized the ASPEN heat and mass balance results in Appendix A. The results are organized around the major components of the system. 


\subsubsection{Modeling Approach and Methodology}

The overall approach used in this study was to use accepted chemical process engineering methodology. The overall process was modeled by using the commercially available ASPEN Plus process simulation software package. Major components were modeled rigorously. The fuel cell stacks were modeled within ASPEN using a rigorous FORTRAN model. The gas turbine (compressor and turbine) was modeled rigorously using the software package GATE/CYCLE. The results from the rigorous model were compiled into a curve fit, and the curve fit was incorporated into the ASPEN process simulation. The recuperator and fuel heater were also modeled separately, and the results incorporated into the simulation.

A simplified process flow diagram was generated for this report, as shown in Figure 2. Also included is a simplified stream summary in Table 1, and a component duty summary in Table 4.

A performance map was constructed using the method developed in Reference 4 to aid in analyzing the PSOFCs. Detailed stack models have been used to predict PSOFC response to changes in operating conditions. Integrated into a process model, the results yield accurate predictions of system performance. Results from a number of cases may be assembled to construct performance maps. While these models provide detailed resolution of processes and conditions, they are complex and cumbersome for operating point analysis and optimization. Since the performance of the system is highly dependent on the performance of the fuel cell stacks, a more useful approach is to define relationships that govern stack performance. These relationships are then combined to create a closed form parametric model suitable for application in the construction of performance maps and operating point optimization and analysis. The governing performance parameters for PSOFC stacks are fuel flow, area specific resistance, and operating voltage. The functional form of the model and the boundaries of the operating envelope provide useful insight into PSOFC operating characteristics and an improved means of guiding the selection of economically viable operating conditions. The performance map is discussed in Section 2.2.1.

Modeling of Engine Performance

Prediction of detailed engine performance has been carried out using the GateCycle code developed by Enter Software (Menlo Park, CA) in conjunction with NREC performance models. This approach relies on turbomachinery performance maps whose broad characteristics are simulated using NREC software, but which have been calibrated in detail based on component test data. One exception is the power turbine whose performance is entirely based on a model simulation, given that this component is to be redesigned and no test data are available.

Pressure losses at nominal design conditions are shown in Table 8, with approximate corrections applied at off-design flow conditions. 


\begin{tabular}{|l|l|}
\hline \multicolumn{2}{|c|}{ Table 8 Component Pressure Loss } \\
\hline Component & $\Delta \mathrm{p} / \mathrm{p}$ \\
\hline Inlet filter/ducting & $0.5 \%$ \\
\hline Recuperator cold-side & $1.0 \%$ \\
\hline Recuperator hot-side & $3.2 \%$ \\
\hline Starting/preheat combustor & $2.5 \%$ \\
\hline Fuel-cell module & $2.4 \%$ \\
\hline Module inlet manifold & $0.8 \%$ \\
\hline Module exit manifold & $0.5 \%$ \\
\hline Fuel preheater & $0.7 \%$ \\
\hline Exhaust ducting & $0.3 \%$ \\
\hline
\end{tabular}

Pressure loss for the PSOFC module was supplied by MTI based on laboratory measurements, plus a conservative allowance for ducting. Other component pressure losses were based on NREC measurements for existing hardware, applying estimated corrections where appropriate. These specifications formed the basis for duct sizing in the conceptual designs presented earlier.

For prescribed turbomachinery performance together with the specifications above, engine behavior is governed entirely by turbine-inlet and ambient temperature (TIT and $\left.\mathrm{T}_{\mathrm{amb}}\right)$. Engine output electrical power and flow conditions delivered to the PSOFC are summarized in Figures 11 through 13 over the anticipated range in these parameters.

Recuperator effectiveness does not enter directly into engine performance projections, but this parameter does govern the TIT that will be achieved at a given operating condition. For the proposed recuperator, a conservative design-point projection for airside effectiveness exceeds $90 \%$, defined by $\varepsilon=\left(T_{3}-T_{2}\right) /\left(T_{13}-T_{2}\right)$. This projection results in overall recuperator dimensions roughly equal to those of the current PowerWorks engine. Figure 14 shows the effect of recuperator hot-side inlet temperatures corresponding to the projections of Figures 11 through 13, based on the conservative effectiveness value of $90 \%$ (assumed constant throughout the operating range). From the plot it's evident that recuperator-inlet temperature is largely a function of TIT, because compressor-discharge temperature doesn't vary over wide limits.

Figures 11 through 14 demonstrate that TIT and $\mathrm{T}_{\mathrm{amb}}$, or more roughly the engine temperature ratio $\mathrm{TIT} / \mathrm{T}_{\mathrm{amb}}$, exert substantial impact on engine output and flow. This means that sensitive control of PSOFC flowrate can be achieved by modulating the recuperator-inlet temperature $\left(\mathrm{T}_{13}\right)$, which depends in turn on the rate of fuel supply to the burner/reformer.

The detailed projections of Figures 15 through 18 were useful in characterizing engine performance for purposes of the MTI integrated system model. Here the engine is represented in simplified form as a single compressor and turbine each having prescribed efficiency, pressure ratio, and flowrate. To support application of this model for three 
values of $\mathrm{T}_{\mathrm{amb}}$ spanning the projected operating range $(0 \mathrm{~F}, 59 \mathrm{~F}, 100 \mathrm{~F})$, the required inputs were generated as functions of TIT by performing detailed off-design simulations, yielding the results of Figures 15 through 18. The curve fits shown were then incorporated into the integrated system model.

Some minor simplifications were made in carrying out this procedure. A constant mechanical loss equal to $2 \%$ of overall turbine power, and a generator shaft-to-electrical efficiency of $94 \%$ were assumed. Although more accurate prescriptions are made in the full GATE/CYCLE off-design model, discrepancies are very small. A further modeling difference is that a single overall expansion efficiency was used for the two-turbine system, but this introduces no error with respect to the thermodynamic variables presented to the PSOFC system. 
Power-Turbine Exhaust Temperature

(PSOFC inlet)

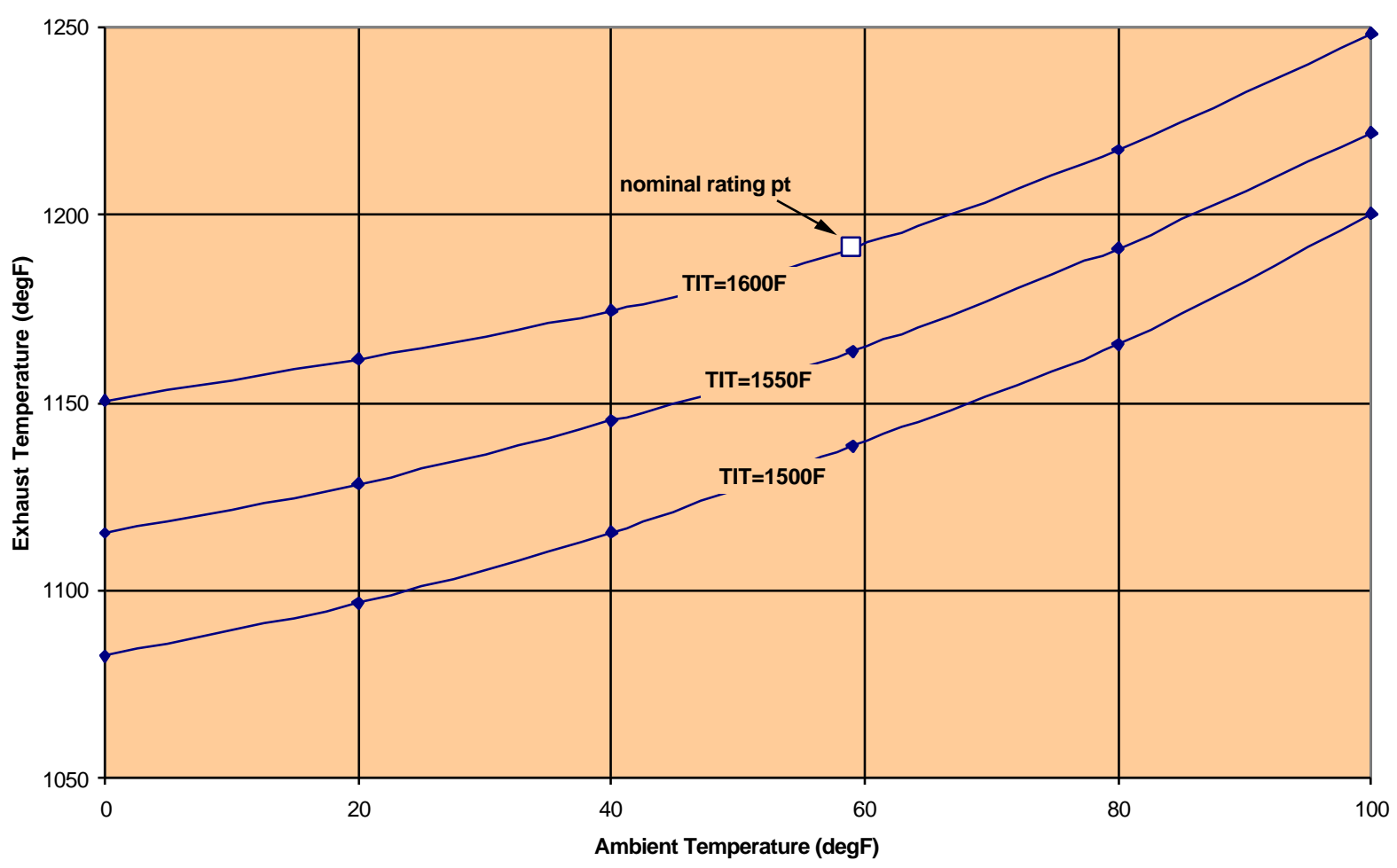

Figure 11 Exhaust Temperature

Compressor Flow (delivered to PSOFC)

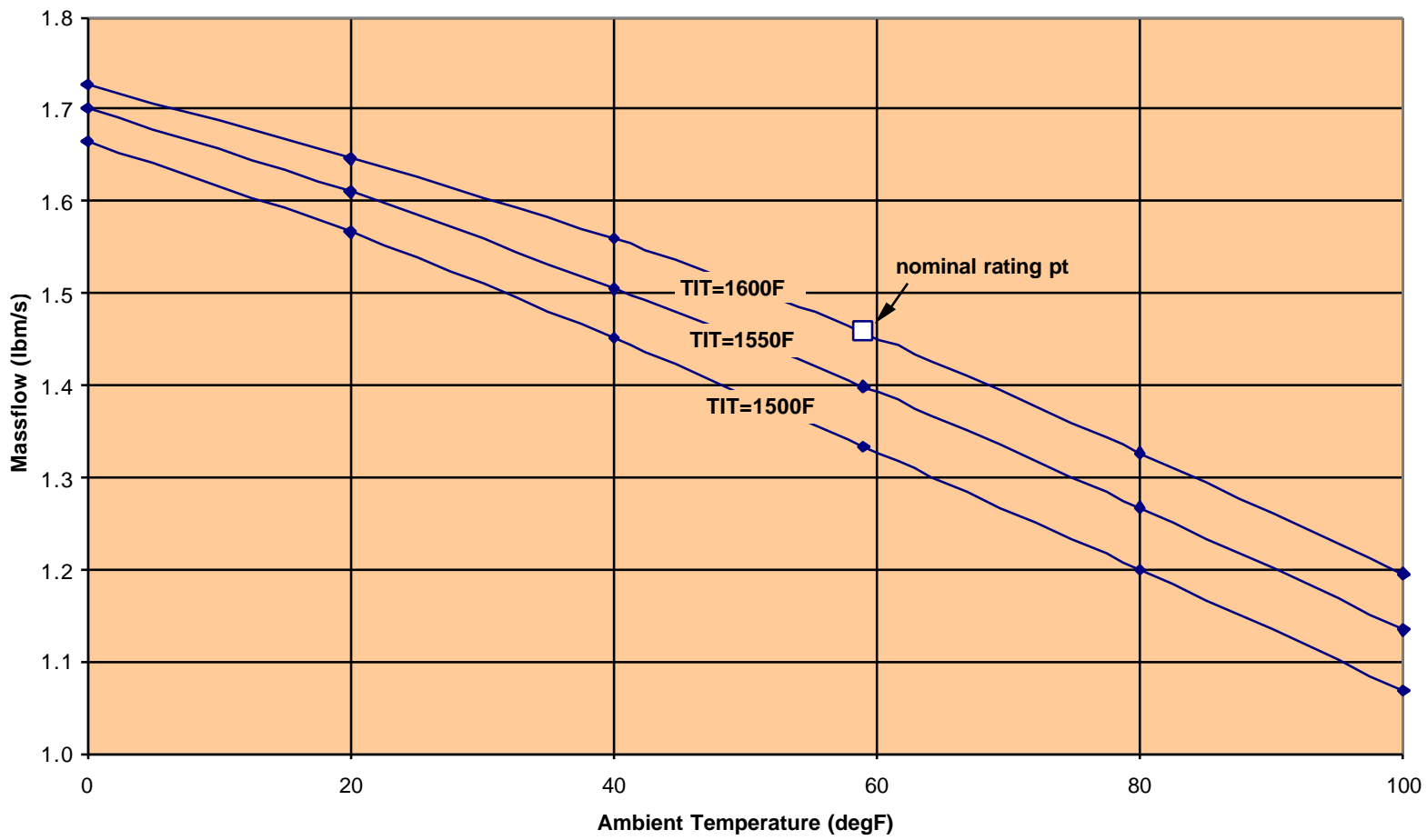

Figure 12 Compressor Flow 
Engine Electrical Power Output

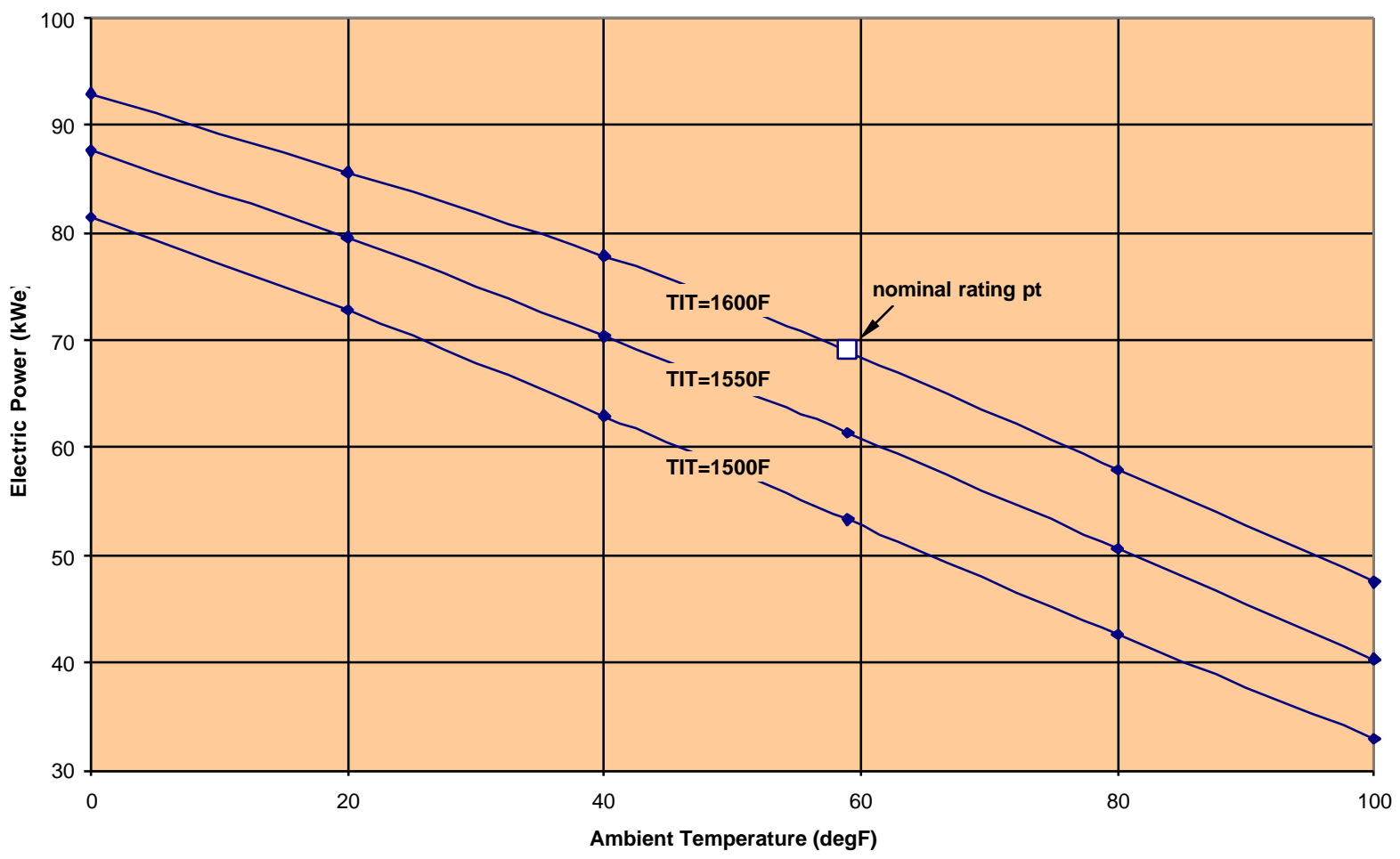

Figure 13 Engine Electrical Power Output

Hot-Side Recuperator-Inlet Temperature for $\varepsilon_{\mathrm{Hx}}=90 \%$

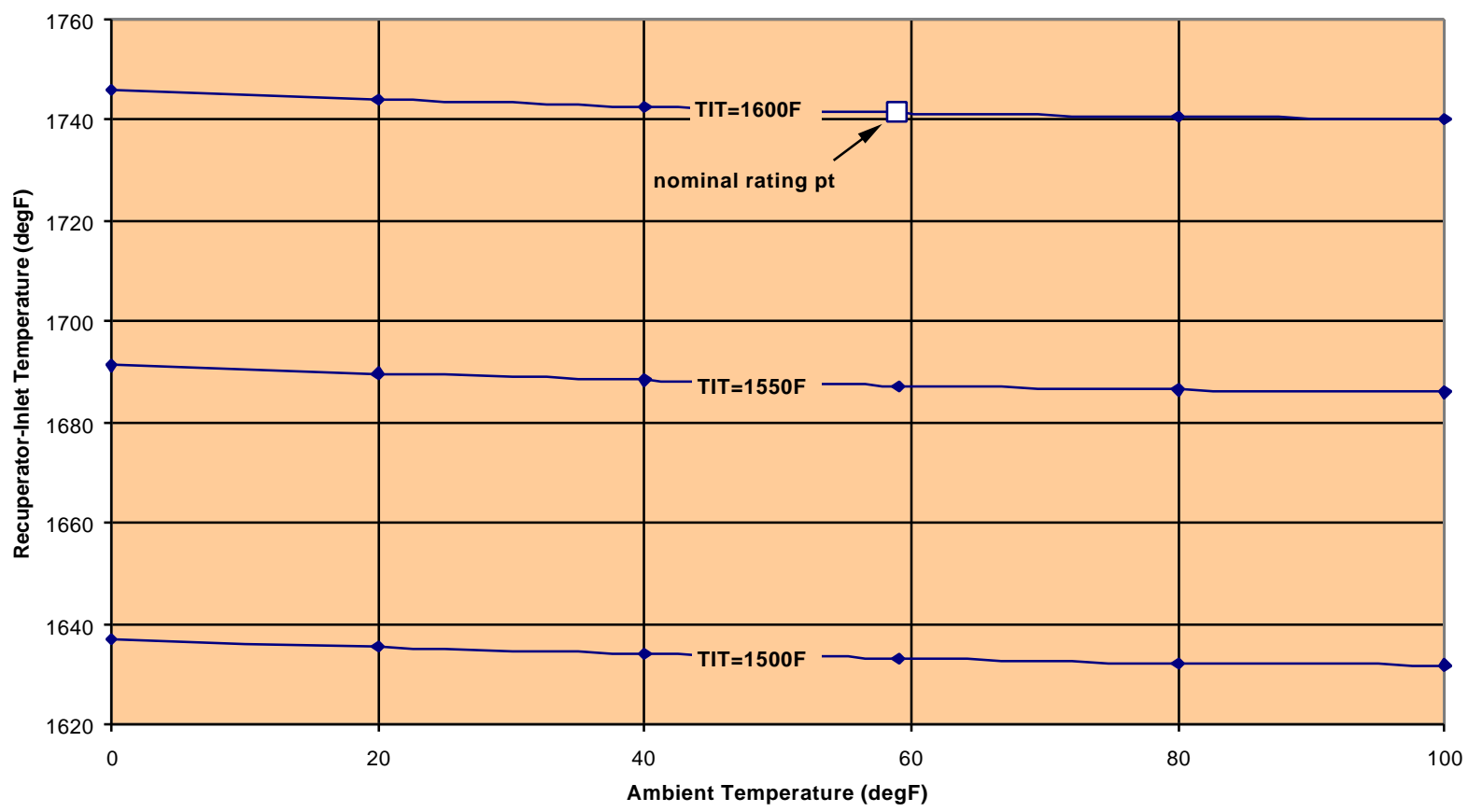

Figure 14 Hot Side Recuperator Inlet Temp. 


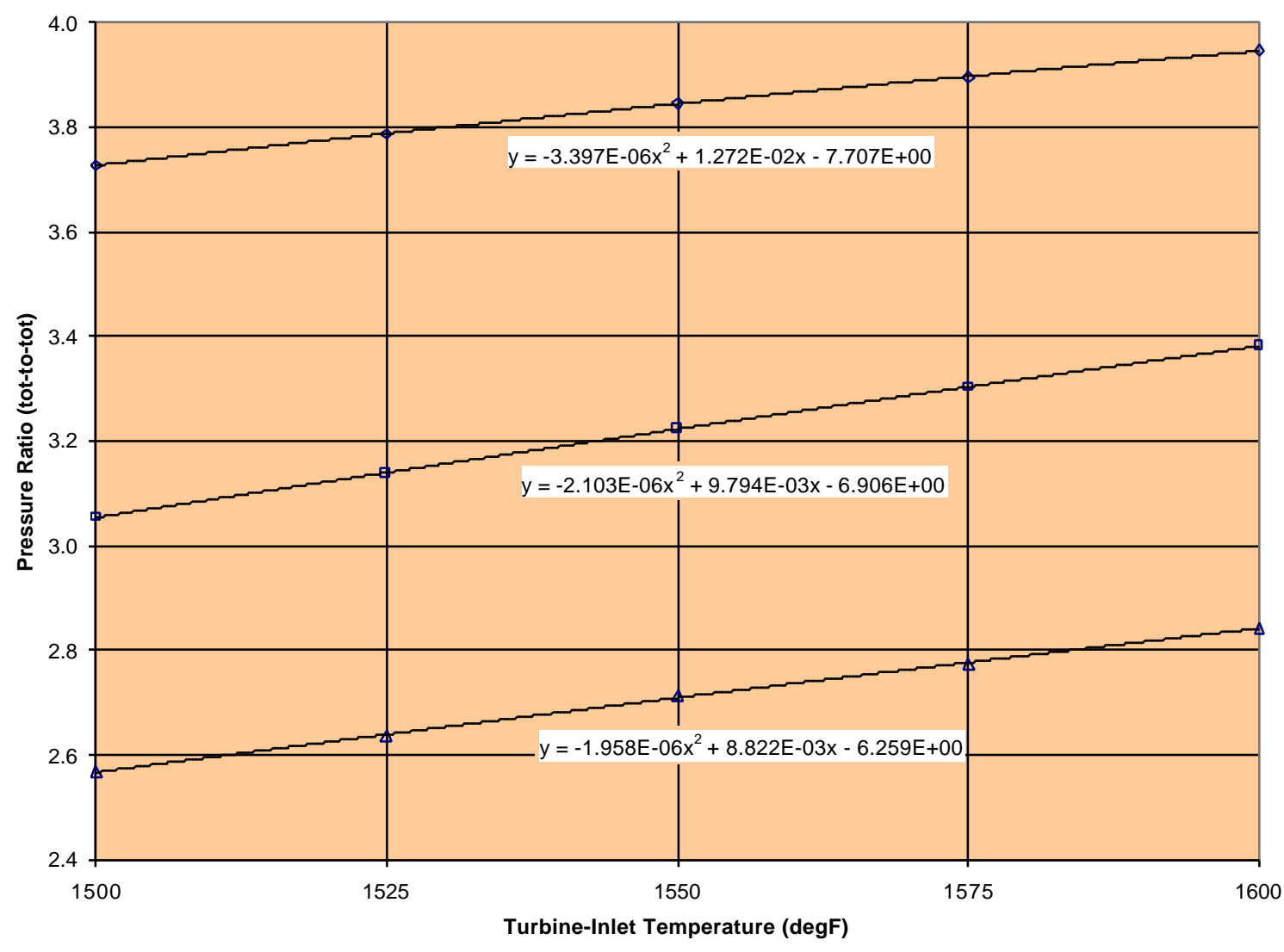

$\diamond \mathrm{Tamb}=0 \mathrm{~F}$

口 Tamb $=59 \mathrm{~F}$

$\Delta \mathrm{Tamb}=100 \mathrm{~F}$

Figure 15 Compressor Pressure Ratio

Compressor Flow

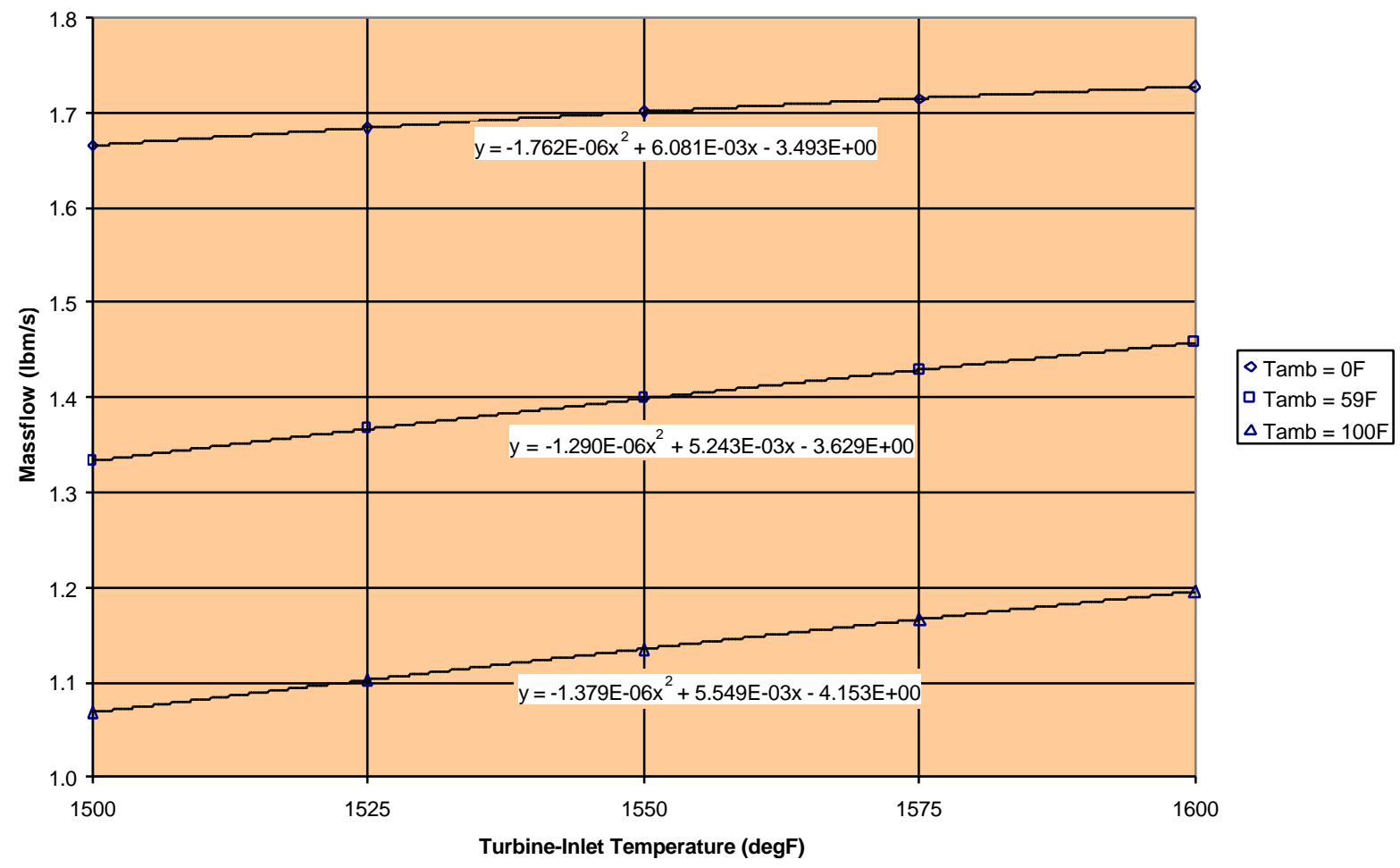

Figure 16 Compressor Flow 
Compressor Efficiency

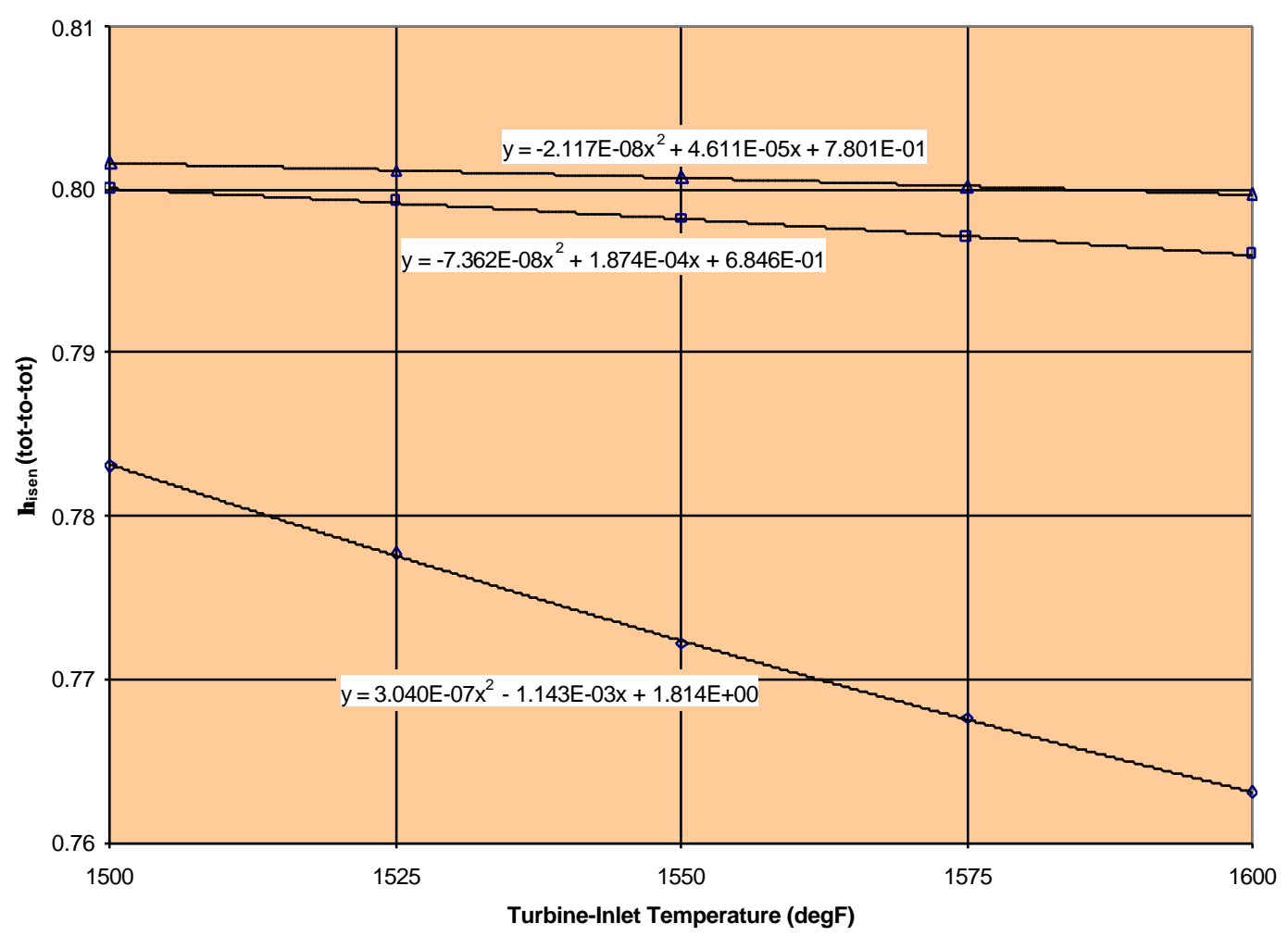

$\triangle \mathrm{Tamb}=0 \mathrm{~F}$

$\square \mathrm{Tamb}=59 \mathrm{~F}$

$\Delta \mathrm{Tamb}=100 \mathrm{~F}$

\section{Figure 17 Compressor Efficiency}

Overall Expansion Efficiency

(effective value for 2-turbine system)

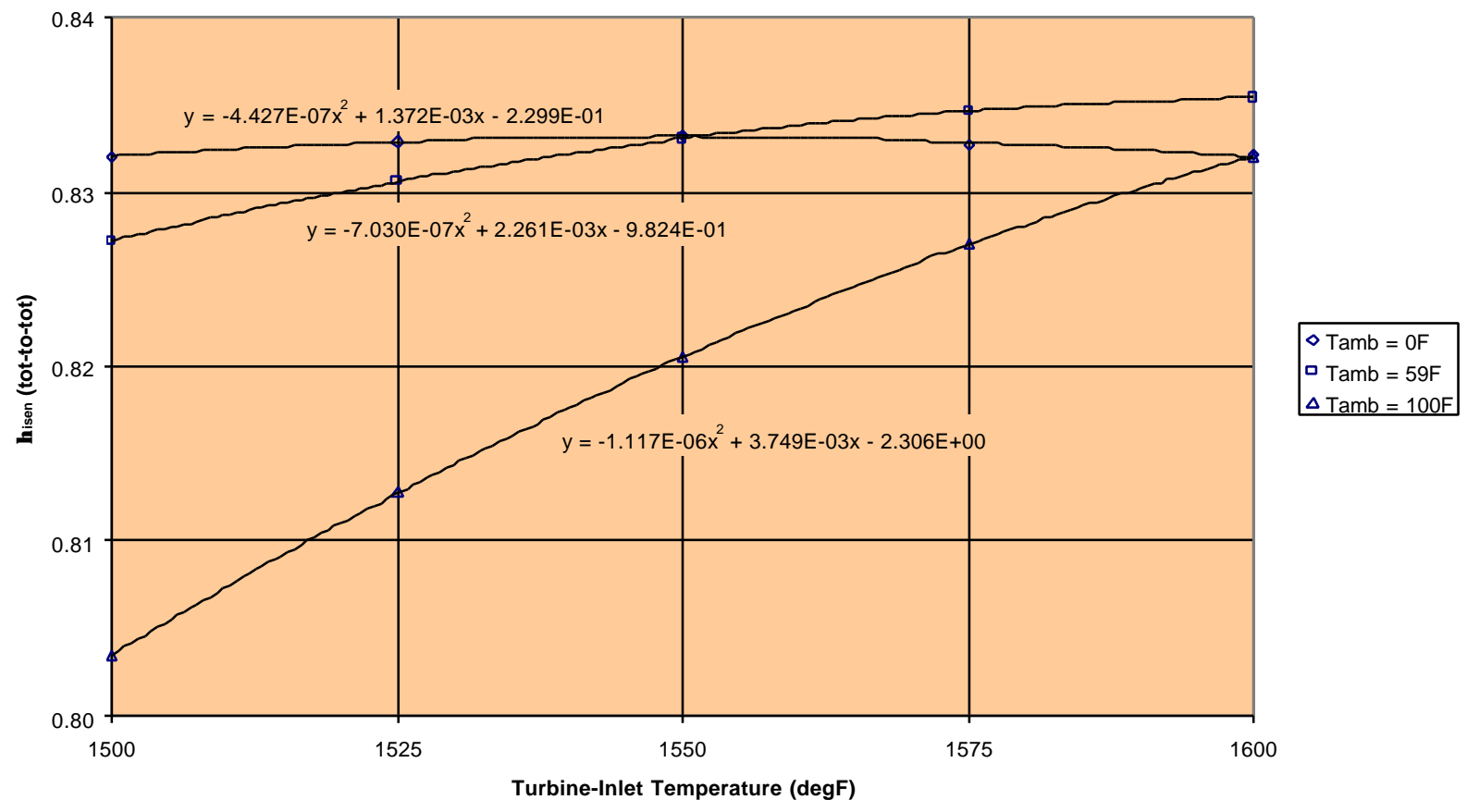

Figure18 Overall Expansion Efficiency 


\subsection{Process/Equipment Uncertainties and Development Requirements}

Having chosen the design flow conditions for the PSOFC power plant that correspond with the capacity of the PowerWorks ${ }^{\mathrm{TM}} 70 \mathrm{~kW}$ engine, most production engine components can be used directly. In particular, no changes are anticipated for the compressor or high-pressure turbine and associated ducting. Starting, lubrication, and fuel-delivery systems will also remain unchanged. Redesign of the combustor and wasteheat recovery system (now fuel preheater) will be relatively minor, with the overall dimensions and packaging for these components unaffected (see below).

The power turbine is the single exception to the application of production hardware. Although the turbine rotor can be used without modification, the stationary housing will require rework in order to accommodate the increased pressure loss introduced by the PSOFC system. The impact of this pressure loss would be reduced pressure-ratio across the gasifier turbine, limiting engine power and flow especially on hot days. The change to the power turbine housing will increase the power-turbine flow capacity.

Redesign of the combustor is dictated by the need to minimize pressure loss at design conditions, where the combustor is switched off and represents a parasitic loss. Combustor inlet temperature is approximately $1200 \mathrm{~F}$ at nominal PowerWorks ${ }^{\mathrm{TM}}$ design conditions, but for the proposed application this value increases to $1600 \mathrm{~F}$. Relatively straightforward design changes should make it possible to hold pressure loss within the $2.5 \%$ design specification, which is required for stable combustor performance during starting and preheat. Cold-flow testing of the redesigned combustor is planned in order to meet these objectives.

Adaptation of the current PowerWorks ${ }^{\mathrm{TM}}$ heat-recovery system to meet fuel preheating demands is largely a matter of substituting a redesigned heat-exchanger core for the current commercial finned-tube unit. The present device supplies hot water at a constant temperature, as achieved by pivoting the core out of the flow path under thermostatic control. For the proposed application this pivoting feature is probably unnecessary, because the fuel demand does not vary widely and precise control of the delivery temperature is less critical.

\subsubsection{Fuel Cell Issues}

The power and efficiency realized by operation of Solid Oxide Fuel Cell (PSOFC) systems are determined not only by the stack characteristics, but also by the operating conditions. The choice of operating conditions enable a wide range of delivered power and efficiency from a particular PSOFC device. Operating parameters may be selected to maximize power while constraining efficiency, maximize efficiency while constraining power, or optimization of a function of both variables such as cost of electricity. While detailed stack models may be used to predict PSOFC response at a specific operating point, these complex models are unnecessarily cumbersome for operating point analysis and optimization. Relationships between fuel flow, area specific resistance, and operating voltage were defined to develop a closed form parametric model. This model 
was applied to construct a performance map for operating point analysis and economic optimization. The functional form of the model and the boundaries of the operating envelope provide useful insight into PSOFC operating characteristics and a simple means of selecting operating conditions.

The choice of stack temperature, fuel flow, and operating voltage enable a wide range of delivered power and efficiency from a particular PSOFC device. Thus, the challenge of formulating a relationship between PSOFC power and efficiency in terms of controllable operating parameters is undertaken. It has been shown that the stack efficiency can be expressed simply in terms of operating voltage, fuel utilization, and thermoneutral voltage (Reference 1).

$\eta_{\text {stack }}=\frac{V_{o p} U}{E_{t n}}$

$\eta_{\text {stack }}=$ fuel cell stack efficiency

$V_{o p}=$ operating voltage

$U=$ fuel utilization

$E_{t n}=$ thermoneutral voltage

Of these three factors, operating voltage is the only independent variable.

Thermoneutral voltage is a property of the fuel defined as the heating value of the fuel divided by the number of Faradays of charge resulting from complete electrochemical oxidation of the fuel.

$$
E_{t h}=\frac{\Delta H}{n F}
$$

where:

$\Delta \mathrm{H}=$ molar heating value of the fuel (LHV) for methane $890.347 \mathrm{~kJ} / \mathrm{g}$ - mole

$\mathrm{n}=$ number of electrons transferred per molecule of fuel to completely oxidize the fuel, 8 for methane

$\mathrm{F}=$ Faraday's number, 96,487 Coulombs per $\mathrm{g}$ - mole

Utilization, defined as the ratio of delivered current to stoichiometric current, is an outcome which is dependent on stack resistance, operating voltage and fuel flow rate.

$U=\frac{I}{\dot{n} n F}$

where:

$\mathrm{I}=$ delivered current

$\dot{n}=$ fuel flow rate

$\mathrm{n}=$ number of electrons transferred per molecule of fuel to completely oxidize the fuel, 
8 for methane

$\mathrm{F}=$ Faraday's number, 96,487 Coulombs per $\mathrm{g}$ - mole

For a given stack resistance and fuel composition, the only independent variables available to effect changes in power and efficiency are operating voltage and fuel flow rate. Stack resistance is of course a function of operating temperature. However, operating temperature is not considered as an independent variable here as it is assumed that to minimize resistance, the stack is operated at the highest temperature consistent with stack life and system balance of plant constraints.

It would appear from equation [1] that a high operating voltage is required for high efficiency. At a fixed fuel flow rate however, utilization declines with increasing operating voltage. Power also decreases as operating voltage is raised from the maximum power voltage which in common experience is slightly less than half the open circuit voltage $(\mathrm{OCV})$. The greatest efficiency at any given fuel flow is obtained at the operating voltage which results in the highest power output.

Detailed system models were used in this program to predict overall system performance for a range of parameters. While these models provide detailed resolution of processes and conditions in the stack or balance of plant, they are unnecessarily complex and cumbersome for operating point analysis and optimization. A more useful approach is to define relationships between fuel flow, area specific resistance, and operating voltage. These relationships can then be combined to create a closed form parametric model suitable for application in the construction of performance maps and operating point optimization and analysis. The functional form of the model and the boundaries of the operating envelope, provide useful insight into PSOFC operating characteristics and an improved means of selecting operating conditions. Since the PSOFC is the highest efficiency and highest cost components the results of the PSOFC performance map translate to performance for the entire system.

A useful metric is derived by casting fuel flow rate as an electrochemical term which represents the average current density required for $100 \%$ fuel utilization.

$j_{f}=\frac{\dot{n} n F}{A}$

$j_{f}=$ average current required for $100 \%$ fuel utilization divided by cell area

$A=$ cell area

The driving voltage, or difference between the reversible potential and operating voltage $\left(E_{t n}-V_{o p}\right)$, required to sustain the full utilization current density can then be calculated using the stack area specific resistance (ASR, or $R^{\prime \prime}$ ).

$\Delta V_{f}=j_{f} R^{\prime \prime}$ 
$\Delta V_{f}=$ driving voltage

$j_{f}=$ average current required for $100 \%$ fuel utilization divided by cell area

$R^{\prime \prime} \quad=$ Area Specific Resistance or ASR, $\left(\Omega-\mathrm{cm}^{2}\right)$

Combining equation 4 with equation 5 gives

$\Delta V_{f}=\frac{\dot{n} n F R^{\prime \prime}}{A}$

$\Delta V_{f}=$ driving voltage

$\dot{n} \quad=$ fuel flow rate

$\mathrm{n} \quad=$ number of electrons transferred per molecule of fuel to completely oxidize the fuel, 8 for methane

$\mathrm{F} \quad=$ Faraday's number, 96,487 Coulombs per $\mathrm{g}$ - mole

R" $\quad=$ Area Specific Resistance or ASR, $\left(\Omega-\mathrm{cm}^{2}\right)$

$\mathrm{A}=$ cell area $\left(\mathrm{cm}^{2}\right)$

Assuming that ASR is constant for a particular stack or set of stacks, and that $n$ is a constant for a particular fuel, then the driving voltage is dependant on fuel flow rate and the number of cells (or cell area). Further details of the operating point model may be found in Reference 4.

The performance map will show that optimizing for maximum efficiency will lead to a large stack size and thus a large capital investment. In practice, objectives may dictate selection of an operating point designed to maximize power while constraining efficiency, maximize efficiency while constraining power, or optimize a function of both power and efficiency such as cost of electricity (COE). The relative priorities of efficiency, power, and COE establish the appropriate objectives and constraints.

A map of PSOFC performance in ( $V_{o p}, \Delta V_{f}$ ) space was created using the approach developed in Reference 4. These results are for a plug flow PSOFC configuration (e.g., cross flow or counter flow) under isothermal conditions at $800{ }^{\circ} \mathrm{C}$. Inlet fuel composition was methane with 2.0 steam to carbon ratio. The RAS was specified at 0.5 $\Sigma$ - $\mathrm{cm}^{2}$. The utilization parameter was varied from 0.3 to 0.98 , while the $\Delta V_{f}$ parameter (representative of fuel flow and cell area) varied from 0.095 to 0.7 volts. The map of efficiency, power density, current density and utilization in the $V_{o p}, \Delta V_{f}$ plane is shown in Figure. The domain is bounded to the right (high operating voltage) by utilization falling below $30 \%$ and to the left (low operating voltage) by utilization exceeding $98 \%$.

Several interesting observations can be made by a thorough examination of this mapping. There are two operating regimes demarked by the kink in the high utilization boundary. At values of $\Delta V_{f}$ less than about 0.2 volts, power is fuel flow limited, while above 0.2 
volts $\Delta V_{f}$, power is resistance limited. The location of the transition is a function of ASR. Power drops by about half from the point of maximum power to the point of maximum efficiency. Efficiency drops by a similar ratio between the high efficiency and high power points. At a constant fuel flow (lines of constant $\Delta V_{f}$ ), the operating voltage for maximum efficiency and maximum power coincide. Along a line of constant efficiency, maximum power is achieved at the greatest fuel flow $\left(\Delta V_{f}\right)$ possible.

For the PSOFC/Micro-Turbine combined cycle with a net system efficiency of greater than $70 \%$, the operating point for the fuel cell is at an efficiency of $68 \%$. As is shown in Figure, this shifts the operating point to the extreme lower right corner of the performance map. The lower right corner of the performance map corresponds to a high $V_{o p}$ and a low $\Delta V_{f}$. Operating at high $V_{o p}$ results in low power density for a given stack.

For a given fuel flow and stack ASR, operating at low $\Delta V_{f}$, requires a large stack area, as is shown by inspection of Equation 6. A large stack area requires many fuel cells and fuel cell stacks. Until PSOFCs become the low cost component in the PSOFC/MicroTurbine cycle, optimizing the system economically will result in a system that has less fuel cell area than the system that is optimized on efficiency. The $18 \mathrm{MW}$ system described above, would require over 18,000 square meters of cell area. Clearly for an economically viable market introduction, the cell area must be reduced.

A judiciously selected operating point is essential to extracting the most value from a PSOFC installation. The closed form parametric model presented in Reference 4 was used to create a performance map to aid the process of understanding economical operating point selection. The form of the model and the boundaries of the performance maps also provide insight valuable in the selection process. A commonly stated goal of high operating voltage (e.g., $0.7-0.8 \mathrm{~V}$ ) is not expected to be the highest efficiency point except at relatively low fuel flows and high cell area. It can be shown, by inspection of Figure 15, that curves of efficiency are highest in the lower right corner, and curves of power density are highest in the upper left corner. Therefore, commonly quoted goals for high efficiencies and high power densities are not likely to be achieved simultaneously. 


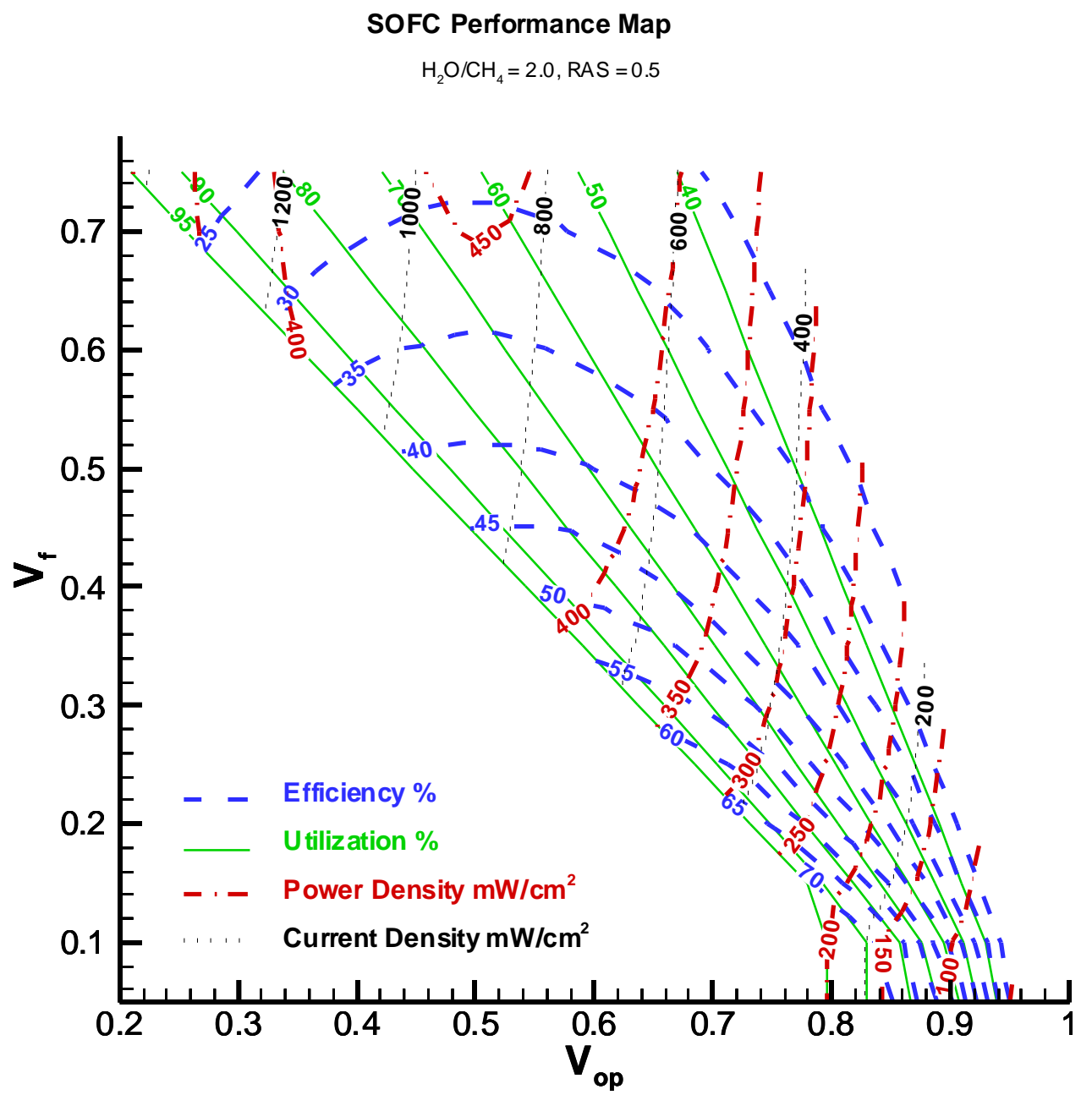

Figure19: PSOFC Performance Map 


\subsection{System Capital Costs - Nth of a Kind Projections}

Based upon a 727kW sized system described in Section 2, two primary subsystems were analyzed with regard to both existing and nth of a kind cost estimates. Using 50 units as the nth of a kind volume for both the microturbine subsystem and for the fuel cell related subsystem, estimates include capital costs, variable operating costs and replacement costs.

Using MTI's proprietary “Upgrades and Enhancements Financial Evaluation Program" software and incorporating a industry recognized standards for Cost of Electricity (COE) calculation, a wide variety of plant equipment, operations, and variable cost simulations were conducted to evaluate different scenarios for system configuration. Using the system described within Section 2, component costs were compiled and nth of a kind costs were estimated based upon; volume manufacturing cost reductions, technology innovations leading to lower material, process and manufacturing costs, and performance enhancement to component and system operations leading to lower cost components.

Initial installation nth of a kind capital costs (including a 10\% installation charge) were $\$ 454,850$ for the $727 \mathrm{~kW}$ system leading to a $\$ 625 / \mathrm{kW}$ capital cost. Nth of a kind microturbine subsystem costs were $\$ 85,000$ and fuel cell subsystem costs accounted for the remaining $\$ 328,500$ (excluding the $10 \%$ installation charges in both cases).

In addition to the initial capital costs, a conservative approach to one-time fixed costs (assuming non-depreciable capital costs) was utilized to replace both subsystems (in their entirety) at the end of each subsystems assumed lifetime (multiple times over the 25 year plant life). Using an 80,000 hour lifetime for the microturbine subsystem and a 40,000 hour assumed lifetime for the fuel cell subsystem, the following fixed cost capital replacement schedule represents overall capital costs over the 25 year plant life.

\begin{tabular}{|l|c|c|}
\hline \multicolumn{3}{|c|}{ Table 9 PSOFC/Microturbine Capital Costs } \\
\hline \multicolumn{1}{|c|}{ ITEM } & YEAR & COST \\
\hline $\begin{array}{l}\text { Initial Capital Cost (Fuel Cell/ Microturbine) } \\
\text { Subsystems with 10\% Installation Factor }\end{array}$ & 1998 & $\$ 454,850$ \\
\hline Fuel Cell System Replacement & 2003 & $\$ 361,350$ \\
\hline $\begin{array}{l}\text { Fuel Cell System Replacement \& Microturbine } \\
\text { System Replacement }\end{array}$ & 2008 & $\$ 454,850$ \\
\hline Fuel Cell System Replacement & 2013 & $\$ 361,350$ \\
\hline $\begin{array}{l}\text { Fuel Cell System Replacement \& Microturbine } \\
\text { System Replacement }\end{array}$ & 2018 & $\$ 682,275^{*}$ \\
\hline
\end{tabular}

*Includes pro-rated capital costs for subsystems whose lifetimes do not exactly fit into the 25 year plant life period assumed in the case. 


\subsection{ANNUAL OPERATING COSTS}

A number of different assumptions were employed to estimate nth of a kind operating costs for the system. These include:

- $70 \%$ efficiency for the system,

- Capacity Factor: 50/52 Week Operating @ 92\% Capacity = 88.4\% overall capacity (with $56.33 \mathrm{MWh} /$ Year electric generation),

- Cost of Capital at $15 \%$,

- Cost Basis of mid-1998 U.S. Dollars,

- COE Evaluation Method using Constant Dollars,

- Cost of Natural Gas at \$3.00 MM Btu (HHV),

- 1/3 man year of operator labor (at a total cost of $\$ 93,951 /$ year),

- $\$ 36,000 /$ year maintenance,

- Water usage costs of $\$ 1.54 /$ day.

Using the MTI's "Upgrades and Enhancements Financial Evaluation Program" software to determine COE, a total COE (including Levelized Capital, Variable Cost and Fixed Cost is 5824 mills/kWh or $5.824 \phi / \mathrm{kWh}$.

\subsection{OPPORTUNITIES FOR IMPROVEMENT AND SUGGESTED WORK}

The key to successful development of this technology is reduced component costs and higher fuel cell power output. Reducing the component cost and increasing cell power output is the objective of the SOFCo fuel cell development program. Other key issues to be resolved involve the integration of the major components and their controls into a functional package. We believe the best way to demonstrate the technology while minimizing costs and reducing uncertainty is to develop a proof of concept demonstration.

\subsubsection{Proof of Concept Demonstration - $180 \mathrm{~kW}$ System}

A proof of concept that includes all components of the full-scale system can be demonstrated at $180 \mathrm{~kW}$. The demonstration would include a full-scale engine. The recuperator would be slightly smaller than full scale as the recuperator hot side inlet temperature is higher. The fuel heater would also be slightly smaller than full scale as the fuel side flows are lower. Both the recuperator and fuel heater would require a moderate increase in surface area to achieve full scale. The major departure from full scale is that only one fuel cell module would be included. The module can be demonstrated at full scale size, or if full scale stacks are not available for demonstration, the stacks could also be simulated. At the successful conclusion of the proof of concept demonstration, all that would be needed to field a full-scale system would be the inclusion of additional fuel cell modules and ducting.

The process description of the $180 \mathrm{~kW}$ proof of concept demonstration, shown in Figure 23, is similar to the full-scale system described in section 2.1.1. The air is 
compressed in the compressor at a 3:1 pressure ratio. The air is then heated to $1600^{\circ} \mathrm{F}$ in a high temperature recuperator by utilizing exhaust gas from the $\mathrm{Cpn}^{\mathrm{TM}}$ module. The hot, high-pressure air is then expanded through the turbine providing power for the compressor and electrical generation. The turbine produces $69.1 \mathrm{kWe}$ of net electrical power or $39 \%$ of the total. The air is then sent to the fuel cell.

Natural gas is mixed with steam that was generated in the steam generator coil, the mixture is then heated further in the fuel heater. The heated fuel/steam mixture is then sent to the steam reformer. In the steam reformer, the fuel-steam mixture passes over steam reforming catalyst and is processed into hydrogen rich reformate and sent to the fuel cell.

The hydrogen and carbon monoxide in the reformate is electrochemically oxidized in the fuel cell producing electrical power. The fuel cell produces $109 \mathrm{~kW}$ of electrical power or $61.2 \%$ of the total. The unreacted fuel is burned with the fuel cell cooling air in the fuel cell module enclosure, further boosting the exhaust temperature and providing heat to drive the steam reforming reactions in the steam reformer. The hot gas leaving the $\mathrm{Cpn}^{\mathrm{TM}}$ is then sent to the high temperature recuperator where it heats the compressed air, and then is sent to the fuel heater where it heats the fuel and steam mixture. The fuel heater exhaust is used to generate steam to that is mixed with the natural gas. The exhaust exits the process at $259^{\circ} \mathrm{C}$. The exhaust could be used to generate low-pressure process steam or space heating in a cogeneration heat exchanger.

The state parameters for the streams shown in $180 \mathrm{~kW}$ process schematic are listed in Table10. The $180 \mathrm{~kW}$ system design parameters are listed in Table11, and the component duties are summarized in Table 13. The performance for the $180 \mathrm{~kW}$ system is listed in Table 12. 


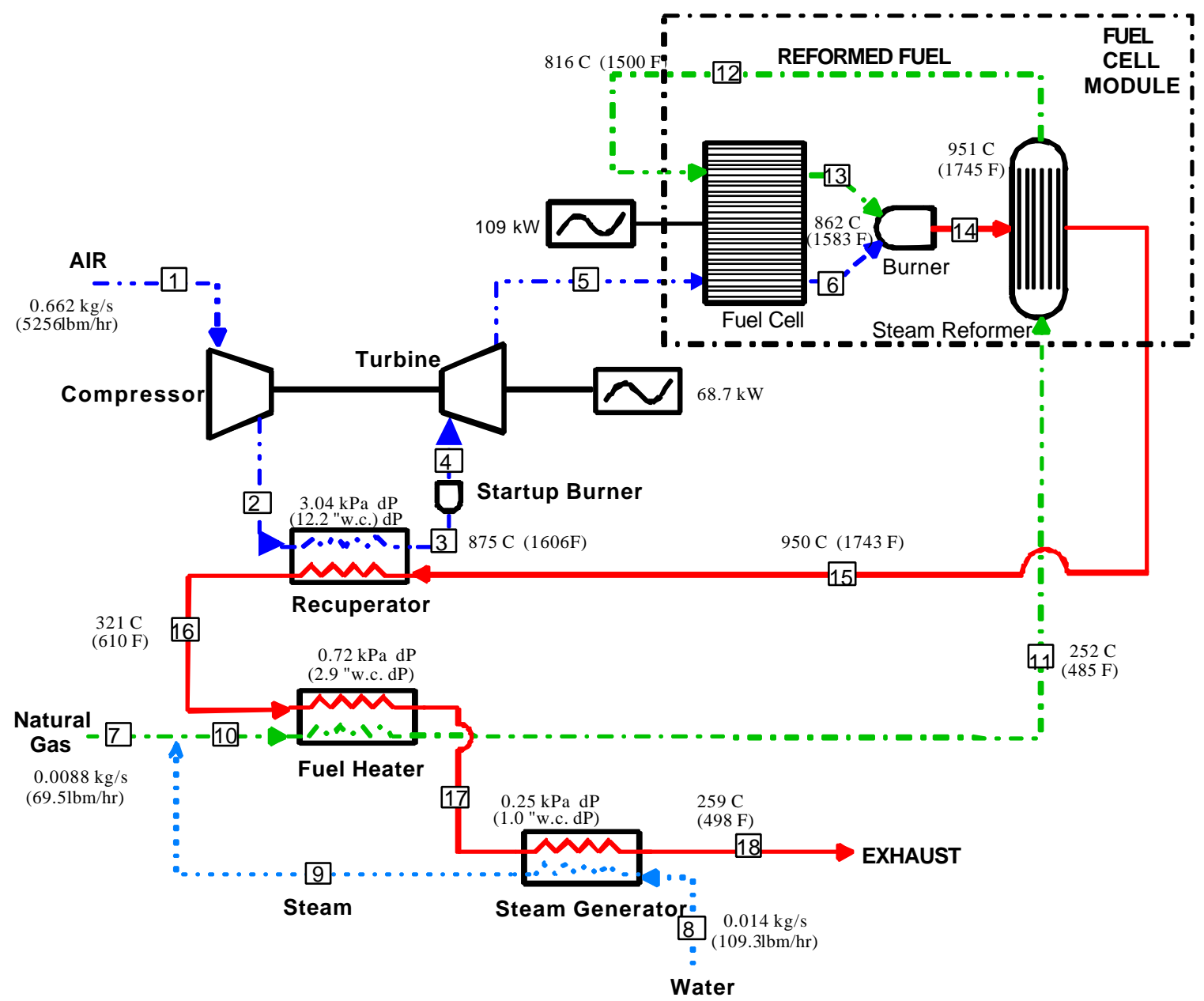

Figure 20: 180 kW PSOFC/MicroTurbine System 


\begin{tabular}{|c|c|c|c|c|}
\hline \multicolumn{5}{|c|}{$\begin{array}{c}\text { Table } 10 \text { - State Parameters For } \\
180 \mathrm{~kW} \text { Fuel Cell/Micro-turbine Combined Cvcle }\end{array}$} \\
\hline State Point & $\begin{array}{c}\text { Flow } \\
\mathrm{kg} / \mathrm{s}(\mathrm{lbm} / \mathrm{hr})\end{array}$ & $\begin{array}{c}\text { Temperature } \\
\mathbf{C}(\mathbf{F}) \\
\end{array}$ & $\begin{array}{l}\text { Pressure } \\
\text { kPa (psi) }\end{array}$ & $\begin{array}{c}\text { Enthalpy } \\
\mathrm{J} / \mathrm{kg}(\mathrm{Btu} / \mathrm{lbm})\end{array}$ \\
\hline 1 & $0.662(5256)$ & $15(59)$ & $101.3(14.7)$ & $-1.35 e 5(-58.04)$ \\
\hline 2 & $0.622(5256)$ & 178 (352) & $304(44.1)$ & $3.11 \mathrm{e} 4$ (13.35) \\
\hline 3 & $0.662(5256)$ & 875 (1606) & $304(44.1)$ & 8.05e5 (346.26) \\
\hline 4 & $0.662(5256)$ & 875 (1606) & $304(44.1)$ & $8.05 \mathrm{e} 5$ (346.26) \\
\hline 5 & $0.622(5256)$ & 642 (1187) & 106.9 (15.5) & $5.35 \mathrm{e} 5$ (228.83) \\
\hline 6 & $0.123(975.7)$ & $862(1583)$ & $106.8(15.5)$ & 7.83e5 (336.50) \\
\hline 7 & $0.009(69.5)$ & $15(59)$ & $204.8(29.7)$ & $-4.74 \mathrm{e} 6(-2037.08)$ \\
\hline 8 & $0.014(109.3)$ & $25(77)$ & $120(17.4)$ & $-1.60 \mathrm{e} 7(-6897.80)$ \\
\hline 9 & 0.014 (109.3) & 108 (226) & $120(17.4)$ & $-1.33 e 7 \quad(-5706.12)$ \\
\hline 10 & $0.023(178.8)$ & $93(200)$ & $120(17.4)$ & $-9.95 e 6 \quad(-4279.84)$ \\
\hline 11 & $0.023(178.8)$ & 252 (485) & $120(17.4)$ & $-9.56 \mathrm{e} 6 \quad(-4109.37)$ \\
\hline 12 & $0.023(178.8)$ & $816(1500)$ & $120(17.4)$ & $-3.16 e 6 \quad(-1359.78)$ \\
\hline 13 & $0.036(286.8)$ & 862 (1583) & $120(17.4)$ & $-7.57 e 6 \quad(-3254.09)$ \\
\hline 14 & $0.685(5434.8)$ & 951 (1745) & $106.8(15.5)$ & $1.33 \mathrm{e} 4$ (14.33) \\
\hline 15 & $0.685(5434.8)$ & 950 (1743) & $106.8(15.5)$ & $3.19 \mathrm{e} 4 \quad(13.71)$ \\
\hline 16 & $0.685(5434.8)$ & $321 \quad(610)$ & $106.8(15.5)$ & -7.17 e5 (-308.25) \\
\hline 17 & $0.685(5434.8)$ & 309 (589) & $106.8(15.5)$ & $-7.30 \mathrm{e} 5(-313.86)$ \\
\hline 18 & $0.685(5434.8)$ & $259(498)$ & $106.8(15.5)$ & $-7.86 \mathrm{e} 5(-337.82)$ \\
\hline
\end{tabular}

\begin{tabular}{|l|l|}
\hline \multicolumn{2}{|c|}{ Table 11 - Desian Parameters for } \\
$180 \mathrm{~kW}$ Fuel Cell/Micro-Turbine Combined Cvcle \\
\hline \hline & Natural gas \\
Fuel & $0.96 \mathrm{CH}_{4}, 0.02 \mathrm{~N}_{2}, 0.02 \mathrm{CO}_{2}$ \\
& $\mathrm{LHV}=4.81 \mathrm{E} 7 \mathrm{~J} / \mathrm{kg}(20,659 \mathrm{Btu} / \mathrm{lbm})$ \\
Turbine pressure ratio & $3: 1$ \\
Recuperator effectiveness & 0.902 \\
Fuel cell & 976 cells \\
Operating voltage & 0.70 V/cell \\
System heat loss & $0.5 \%$ of heat input \\
Inverter efficiency & $95 \%$ \\
Generator efficiency & $98 \%$ \\
Gear box loss & $5 \%$ \\
\hline
\end{tabular}




\begin{tabular}{|l|l|}
\hline \multicolumn{2}{|c|}{ Table 12 - Performance Summarv for } \\
$180 \mathrm{~kW}$ Fuel Cell/Micro-Turbine Combined Cvcle \\
\hline \hline
\end{tabular}

\begin{tabular}{|c|c|}
\hline \multicolumn{2}{|c|}{$\begin{array}{c}\text { Table } 13 \text { - Component Dutv Summarv for } \\
180 \text { kW Fuel Cell/Micro-Turbine_Combined_Cvcle }\end{array}$} \\
\hline $\begin{array}{l}\text { Component } \\
\text { Fuel heater } \\
\text { Reformer } \\
\text { Recuperator } \\
\text { Spent fuel burner } \\
\text { Steam generator }\end{array}$ & \begin{tabular}{|l} 
Duty (kW) \\
$8.9(30,477 \mathrm{Btu} / \mathrm{hr})$ \\
$79.9(272,723 \mathrm{Btu} / \mathrm{hr})$ \\
$512.8(1,749,778 \mathrm{Btu} / \mathrm{hr})$ \\
$-79.9(-272,723 \mathrm{Btu} / \mathrm{hr})$ \\
$38.2(130,233 \mathrm{Btu} / \mathrm{hr})$
\end{tabular} \\
\hline
\end{tabular}




\section{CONCLUSION}

This study has demonstrated that the unique approach taken to combining a fuel cell and gas turbine has both technical and economic merit. By using a micro-turbine, and a non-pressurized fuel cell the total system size has been reduced substantially from those presented in other studies, while maintaining over $70 \%$ efficiency. The reduced system size can be particularly attractive in the deregulated electrical generation/distribution environment where the market may not demand multi-megawatt central stations systems. The small size also opens up the niche markets to this high efficiency, low emission electrical generation option.

While the study has discovered no technical obstacles to success, a sub-scale technology demonstration would reduce the risk of performance and enable a full-scale commercial offering. Demonstrating a full size micro-turbine, with a single fuel cell module would prove the concept as well as the major components and BOP that would be needed in a full-scale system.

The major hurdle to the commercialization of the technology is economics. The costs of major components must be reduced from the present levels. For some components, such as the micro-turbine, volume production may be enough to reduce costs. For the fuel cells, low cost manufacturing, as well as volume production are need to achieve cost projections. 


\section{REFERENCES}

1. J. Hartvigsen, S. Elangovan and A. Khandkar, in Solid Oxide Fuel Cells, S. C. Singhal and H. Iwahara, Editors, PV 93-4, p. 878, The Electrochemical Society Proceedings Series, Pennington, NJ (1993).

2. J. Hartvigsen, S. Elangovan and A. Khandkar, in Science and Technology of Zirconia V, S. P. S. Badwal, M. J. Bannister, R. H. J. Hannink, Editors, p. 682, Technomic Publishing Company Inc., Lancaster, PA (1993).

3. R. Herbin, J. M. Fiard and J. R. Ferguson, in First European Solid Oxide Fuel Cell Forum Proceedings, U. Bossel Editor, p317, Lucerne, Switzerland (1994).

4. J. Hartvigsen, S. Elangovan and A. Khandkar, in Third European Solid Oxide Fuel Cell Forum Proceedings, P. Stevens Editor, p517, Nantes, France (1998). 


\section{APPENDICES}

\section{A. ECONOMIC ANALYSIS}

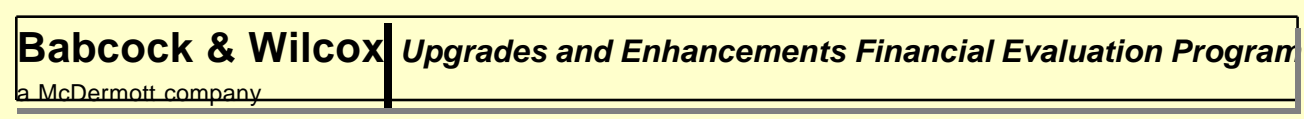

\section{PROJECT INFORMATION SUMMARY}

Project Title

DOE PSOFC/MIDROTURBINE COMBINED CYCLE (727 kW)

Case No.

Customer Data:

Company:

Plant Name:

Unit No(s).

Contact Name:

Contact Phone

Contact Fax:

Contact Electronic Mail Address:

Contact Mailing Address and Other Information

Description

The analysis is for a $727 \mathrm{~kW}$ PSOFC/Microturbine combined Cycle Power Plant that utilizes approximately $650 \mathrm{~kW}$ of PSOFCs and $70 \mathrm{~kW}$ of Microturbine generation to achieve a $70 \%$ efficiency rating

Plant operations assume a 50/52 week operation ( with a planned 2 week service outage and a $92 \%$ capacity factor. Capacity factor input into the B\&W analysis model utilizes a compound capacity factor rate $\left(50 / 52^{*} 92\right)$ to achieve an overall capacity rate of $88.46 \%$

A 25 year total plant live includes stack replacement every 5 years and microturbine replacemnt every 8.33 years. Ancillary equipment replacemnet is included in O\&M costs.

Prepared by 


\section{Babcock \& Wilcox Upgrades and Enhancements Financial Evaluation Program a McDermott company}

\section{UNIT CAPACITY AND OPERATING INFORMATION SUMMARY}

\section{Project Title: DOE PSOFC/IVIDROTURBINE COIMBINED CYCLE (727 kW)}

Case No.:

HEAT RATE DATA

Annual Average Heat Rate

\begin{tabular}{|c|c|}
\hline Base Case (Before this installa & \begin{tabular}{l|l|}
0 & Btu / kWh \\
\end{tabular} \\
\hline Upgrade (After this installation) & \begin{tabular}{l|l}
4,875 & Btu / kWh \\
\end{tabular} \\
\hline Change (Upgrade - Base Case) & \begin{tabular}{l|l}
4875 & Btu / kWh \\
\end{tabular} \\
\hline
\end{tabular}

CAPACITY DATA

\begin{tabular}{|l|l|r|c|}
\hline Net Unit Capacity & Base & 0 & MWe \\
\hline & & 0.727 & MWe \\
\hline & Upgrade & 0.727 & MWe \\
\hline
\end{tabular}

\begin{tabular}{|l|r|r|}
\hline Capacity Factor & Base & $0.88 \%$ \\
& & $0.88 \%$ \\
\hline & Upgrade & \\
\hline & Change & 0.00 \\
\hline
\end{tabular}

\begin{tabular}{|l|l|r|}
\hline Net Annual Generation Rate & Base & 0 MWh / Year \\
& Upgrade & $56.33691 \mathrm{MWh} /$ Year \\
\hline & Change & $56 \mathrm{MWh} /$ Year \\
\hline
\end{tabular}




\begin{tabular}{|l|l|}
\hline $\begin{array}{l}\text { Babcock \& Wilcox } \\
\text { a McDermott company }\end{array}$ & Upgrades and Enhancements Financial Evaluation Program \\
\hline
\end{tabular}

\section{CAPITAL EQUIPMENT COSTS - B\&W and Vendors}

\section{Project Title: DOE PSOFC/MIDROTURBINE COMBINED CYCLE (727 kW) Case No.:}

\begin{tabular}{|c|c|c|c|c|}
\hline \multirow{2}{*}{$\begin{array}{l}\text { Item } \\
\text { No. }\end{array}$} & Description & \multicolumn{3}{|c|}{ Cost } \\
\hline & $\begin{array}{c}\text { [Note: If the material / installation breakout is not } \\
\text { available enter as material] }\end{array}$ & $\begin{array}{c}\text { Material } \\
\text { [\$ US] }\end{array}$ & $\begin{array}{l}\text { Installation } \\
\text { [\$ US] }\end{array}$ & $\begin{array}{l}\text { Total } \\
\text { [\$ US] }\end{array}$ \\
\hline 1 & & $\$ 413,500$ & $\$ 41,350$ & $\$ 454,850$ \\
\hline 2 & & $\$ 0$ & $\$ 0$ & $\$ 0$ \\
\hline 3 & & $\$ 0$ & $\$ 0$ & $\$ 0$ \\
\hline 4 & & $\$ 0$ & $\$ 0$ & $\$ 0$ \\
\hline 5 & & $\$ 0$ & $\$ 0$ & $\$ 0$ \\
\hline & & $\$ 413,500$ & $\$ 41,350$ & $\$ 454,850$ \\
\hline
\end{tabular}

Schedule
Project Conclusion
[In-Service Year]
1998
Project Duration [Start to In-Service] Months

Notes:

1) Project Duration refers to the period during which the customer will incur costs due to carrying the costs for work in progress during construction. Adjustments for these costs are made as the the allowance for funds during construction in theForm 7, Total Capital Cost. If these costs are included in the project capital price entered above then enter 0 months.

2) If significant one-time costs, such as replacement catalysts, are required in out years (after the in-service year) those are addressed in Form 5, Fixed Operating Costs.

3) If a one-time upgrade can be expensed, it may be treated as a one-time- fixed cost in the year prior to the in-service year and entered as a one-time-fixed cost in that year in Form 5,

Fixed Operating Costs.

4) Avoided capital costs may be treated as a negative value here or as an annual credit in Form 5, Fixed Operating Costs. 


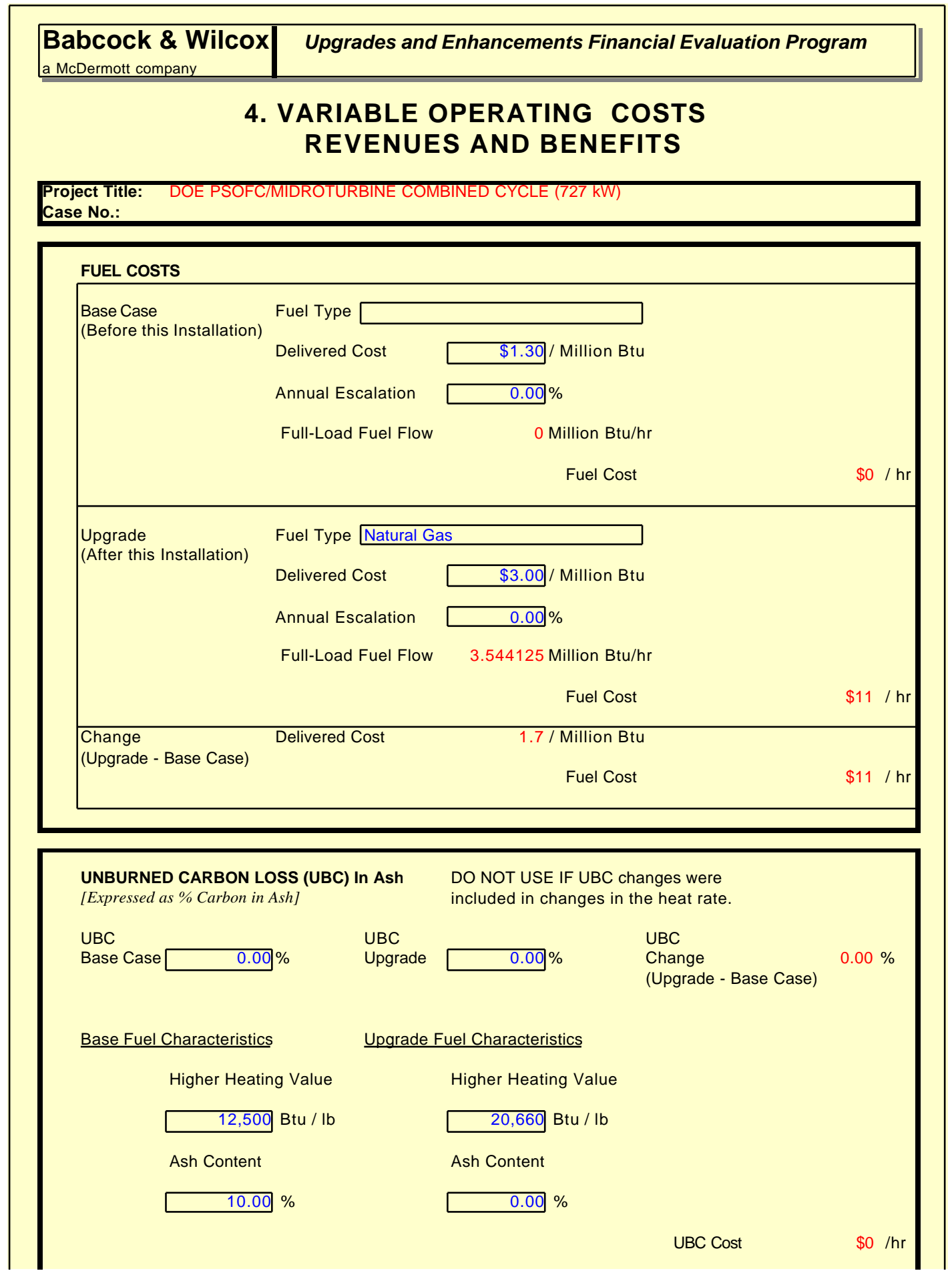


WASTE DISPOSAL - INCREASES IN QUANTITY

\section{Increase in Amount Generated}

Ash

Sludge

Other
0 Tons / hr

0 Tons / hr

0 Tons / hr
Unit Cost of Disposal

Cost / hr

$\$ 9.00 /$ Ton

$\$ 12.00 /$ Ton

$\$ 9.00 /$ Ton

$\$ 0$

Waste Disposal (Increase in quantity) Cost -Subtotal
$\$ 0$

$\$ 0$

WASTE DISPOSAL - INCREASES IN UNIT (\$ / TOn) DISPOSAL COSTS

Total Amount of

Waste Generated

Ash

Sludge

Other

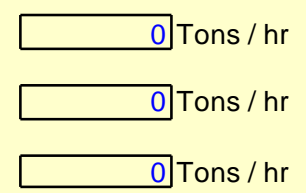

Increase in Unit Cost of Disposal

$\$ 0.00$ / Ton

$\$ 0.00$ / Ton

$\$ 0.00 /$ Ton
Cost / hr

$\$ 0$

$\$ 0$

$\$ 0$

Waste Disposal (Increases in unit disposal price) Cost - Subtotal

CONSUMABLES - INCREASES IN QUANTITY

Increase in Amount Used

Cost / Unit Used

Cost / hr

Raw Water

0.081000 Gals / hr

$\$ 8.00 / 1000$ Gals

$\$ 1$

$\$ 3.50 / 1000$ Lbs

$\$ 0$

Process Steam

0.001000 Lbs / hr

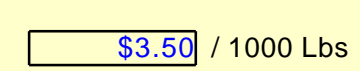

$\$ 18.00 /$ Ton

$\$ 0$

Limestone

0.00 Tons / hr 
CREDITS FOR BYPRODUCTS

Increase in Amount Produced

Credit / Unit

Credit $\$ / \mathrm{hr}$

Steam

0.001000 Lbs / hr

$\$ 0.00 / 1000$ Lbs

Ash

0.00 Tons / hr

$\$ 0.00$ Tons

Gypsum

0.00 Tons / hr

$\$ 0.00$ Tons

Other

\section{ELECTRICITY PRICING}

Electric Power Price

Annual Escalation of Base Price

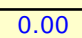

$\$ 0.0000 / \mathrm{kWh}$

Incremental Price (Power Price -(Fuel Cost / kWh x Variable Cost Factor))

Variable Cost Factor $\quad 0.00 \%$

(Non-fuel variable cost shown as percentage of fuel cost)

NET INCREMENTAL REVENUE- Excluding Fuel Cost (Credit From Incremental Net Power Produced)

$\begin{aligned} & \text { Incremental } \\ & \text { Power }\end{aligned}$
$\begin{gathered}\text { Net Incremental Revenue } \\ \text { Except Fuel [Negative cost] }\end{gathered}$
Incremental power produced is automatically calculated from changes in capacity
entered in the Unit Capacity and Operating Information. Increased production due to
capacity factor changes are also included in the total Variable Operating Costs used in
the Cash Flow and Revenue Requirements.

NET VARIABLE COSTS LESS BENEFITS AND LESS INCREMENTAL REVENUE

[Note that incremental revenue considered here is limited to that due to capacity increases only]

NET VARIABLE COSTS (COST LESS BENEFITS) EXCLUDING FUEL COSTS AND INCREMENTAL REVENUE

[Note that UBC \& DGL costs and cost arising from changes in superheater and reheater temperatures and attemperator flow rates are treated under fuel cost considerations and are not included here 


\begin{tabular}{|l|l|}
\hline $\begin{array}{l}\text { Babcock \& Wilcox } \\
\text { a McDermott company }\end{array}$ & Upgrades and Enhancements Financial Evaluation Program \\
\hline
\end{tabular}

\section{FIXED OPERATING COSTS}

Project TItle: DOE PSOFC/IVIIDROTURBIIVE COIVIBIIVED CYCLE $(727 \mathrm{~kW})$

Case No.:

Sign Convention: Cost increases arising from this upgrade or enhancement are positive values ( + ), and cost reductions that result from this upgrade or enhancement are negative ( - ) values.

ANNUAL FIXED COSTS

\section{OPERATING LABOR}

Shift Head-

Count

Increase

[8760 hrs / year]

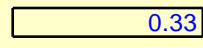

Labor Rate

$\$ 25.00$

Labor

Cost

$\$ 72,270$ / Year
Supervisory,

Overhead and

Gen \& Admin

Cost
Labor +

Supervisory

Cost (Increase)

Subtotal

$\$ 21,681$ / Year

$\$ 93,951$ / Yea

Supervisory Cost in Percent

Labor Cost

\section{MAINTENANCE}

$\begin{array}{crr}\text { Labor } & \text { Materials } & \text { Labor }+ \text { Materials } \\ \text { Cost } & \text { Cost } & \text { Cost Subtotal } \\ \text { Increase } & \text { Increase } & \end{array}$

[Includes Overhead \& G\&A costs]

$\$ 36,000 /$ Year

$\$ 0$ / Year

$\$ 36,000$ / Year

PARTS INVENTORY

$\begin{array}{crr}\text { Inventory } & \text { Annual } & \text { Inventory } \\ \text { Increase } & \text { Rate } & \text { Carrying } \\ & & \text { Cost } \\ & \text { Increase }\end{array}$

Administrative Cost Increase

Subtotal

Increase

$\$ 0 \quad 20.00 \%$

$\$ 0$ / Year

\$0 / Year

$\$ 0 /$ Year

STARTUP FUEL COSTS

Contact B\&W Service Company for Input

$\$ 0 /$ Year 
ONE-TIME (Non-Depreciable) FIXED COSTS - At time of performance

Sign Convention: One-time fixed costs related to this upgrade or

enhancement are positive values (+),

Replacement Power Cost During Outage for Installation of Upgrade or Enhancement Net of Fuel

\{Fuel Cost from VOC $=\$ \quad 0 / \mathrm{Hr}$ form VOC
Outage
Replacement
Power
Capacity
Load
Factor
Cost
Cost
days $\$ 0.060 / \mathrm{kWh}$.
$0 \mathrm{MW}$
$80 \%$
$\$ 0$

OTHER ONE-TIME FIXED COSTS ( Expensed Items that are not Depreciated - Example catalysts replacement) Note: these can be initial project expenses that are not capital expenses. If so, the year should be "year 0 " -- the year preceding the "in-service year."

\begin{tabular}{|c|c|r|r|}
\hline Item & Description & Year & Cost \\
\hline 1 & Stack Replacement & 2003 & $\$ 361,350$ \\
\hline 2 & Stack Replacement/Microturbine Replacement & & \\
\hline 3 & Stack Replacement & 2008 & $\$ 454.850$ \\
\hline 4 & Stack Replacement/Microturbine Replacement & & $\$ 361,350$ \\
\hline & & & \\
\hline & & & \\
\hline
\end{tabular}

Sign Convention: Added revenues arising from this upgrade or enhancement are positive values $(+)$, and reduced revenues that result from this

upgrade or enhancement are negative ( - ) values.

ANNUAL CREDITS for Premuium on Power Sales and Other Benefits

Contact B\&W Service Company for Input

System

$\$ 0 /$ Year

Plant

$\$ 0$ / Year

SUBTOTAL

$\$ 0 /$ Year 
TOTAL OF ANNUAL FIXED COST INCREASES LeSS ANNUAL CREDITS

Does not include "AVOIDED CAPITAL COST CREDIT SHOW BELOW."

TOTAL $\$ 129,951 /$ Year

\section{AVOIDED CAPITAL COST CREDIT}

NOTE: Avoided capital costs may also be treated as a negative capital cost in Form 3. DO NOT APPLY THIS CREDIT IF A NEGATIVE COST WAS USED

FOR THE SAME AVOIDED COST IN FORM 3.

USE CREDIT IN THIS SHEET? $\quad$ ENTER "Y" for yes or "N" for no, here---> $\mathrm{N}$

Incremental Capacity Avoided Capital Cost Capital

Levelization

Factor

$1 \mathrm{MWe} \$ \$ 350 \mathrm{~kW}$ 
\begin{tabular}{|l|l|}
\hline $\begin{array}{l}\text { Babcock \& Wilcox } \\
\text { a McDermott company }\end{array}$ & Upgrades and Enhancements Financial Evaluation Program \\
\hline
\end{tabular}

6. FINANCIAL PARAMETERS

Project Title: DOE PSOFC/MIDROTURBINE COMBINED CYCLE (727 kW)

Case No.:

Evaluation Period

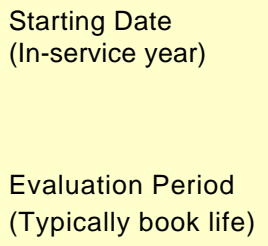

Starting Date

(In-service year)

Evaluation Period

(Typically book life)

Tax Life

$$
\text { Years }
$$

(with $1 / 2$ year convention)

Book Life

$$
\text { Years }
$$

Income Tax Rates

$$
\begin{aligned}
& \text { Federal } \\
& \text { State }
\end{aligned}
$$

Property Tax and

Insurance as Percent

of Capital Equipment Cost

Inflation Rate

$4.000 \%$
Optional User Input

Start Date If there is

no depreciable capital cost

25 Years

Tax Depreciation Rate Table

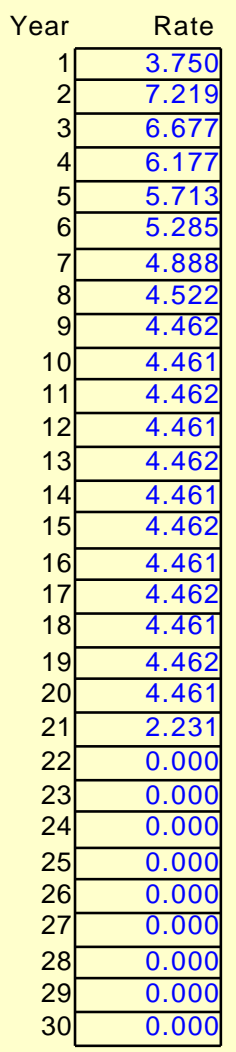

Total

100.000 


\begin{tabular}{|c|c|c|c|c|}
\hline \multicolumn{5}{|c|}{ Discount Rate Calculation } \\
\hline Type of Security & $\begin{array}{r}\text { Percent of } \\
\text { Total } \\
\text { Financing }\end{array}$ & Rate & $\begin{array}{r}\text { Annual } \\
\text { Return } \\
\text { After Tax }\end{array}$ & $\begin{array}{r}\text { Annual } \\
\text { Return } \\
\text { Before Tax }\end{array}$ \\
\hline Debt & $46.000 \%$ & $15.439 \%$ & $4.403 \%$ & $7.102 \%$ \\
\hline Preferred & $8.000 \%$ & $14.939 \%$ & $1.195 \%$ & $1.195 \%$ \\
\hline Common & $46.000 \%$ & $20.439 \%$ & $9.402 \%$ & $9.402 \%$ \\
\hline & Dis & Rate (after tax) & $15 \%$ & \\
\hline Prepared by & 0 & Dat & & 0 \\
\hline
\end{tabular}




\section{Babcock \& Wilcox Upgrades and Enhancements Financial Evaluation Program

\section{TOTAL CAPITAL COST}

Project Title:DOE PSOFC/MIDROTURBINE COMBINED CYCLE (727 kW)

Case No.:

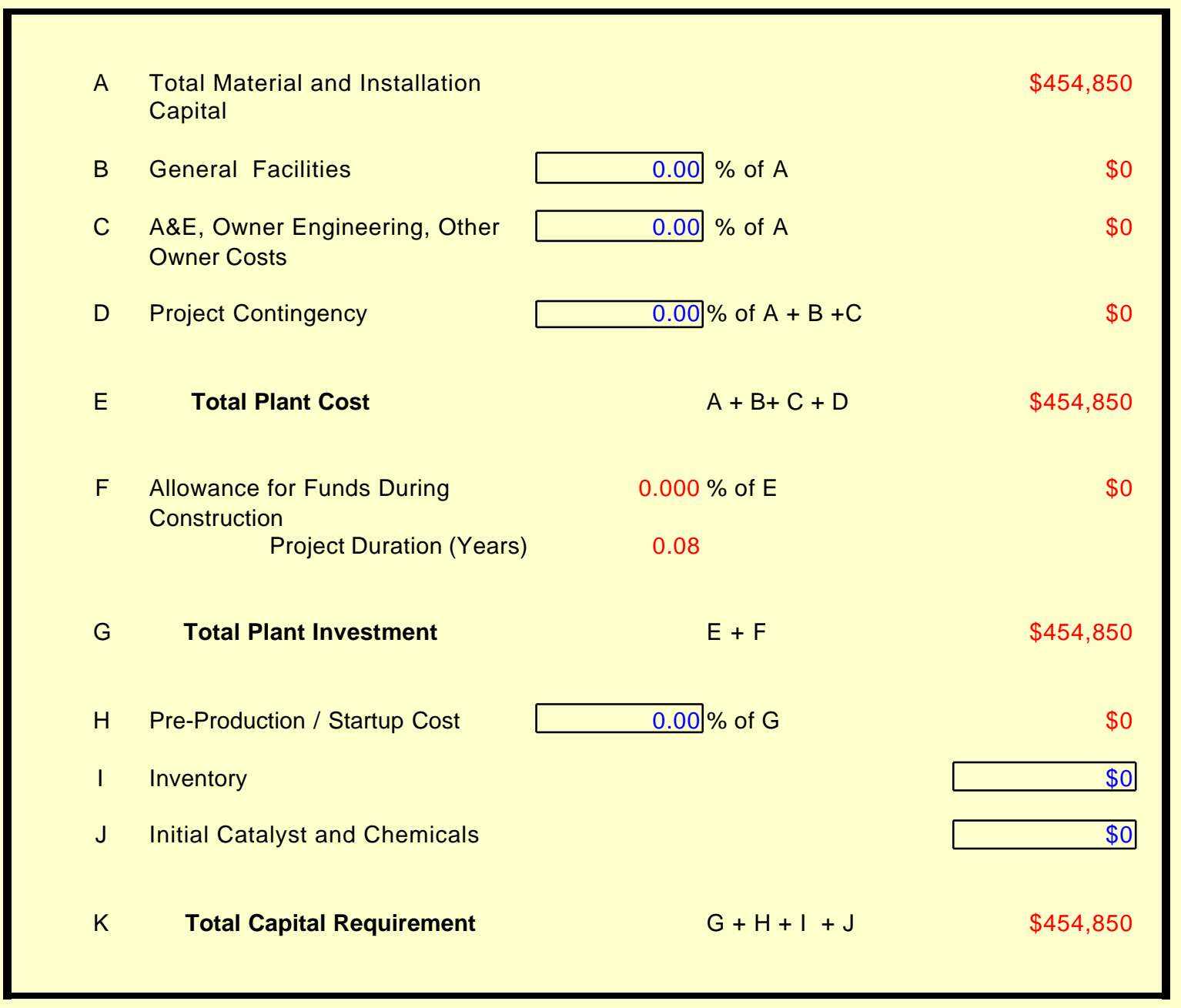




\begin{tabular}{|l|l|}
\hline $\begin{array}{l}\text { Babcock \& Wilcox } \\
\text { a McDermott company }\end{array}$ & Upgrades and Enhancements Financial Evaluation Program \\
\hline
\end{tabular}

\section{ECONOMIC EVALUATION SUMMARY}

Project Title: DOE PSOFC/MICROTURBINE COMBINED CYCLE (727 kW)

Case No.:

CAPITAL COST SUMMARY (at Time of Performance)

Total Depreciable Material and Installation Capital

$\$ 454,850$

Total Depreciable Capital Requirement

$\$ 454,850$

Total One-Time (Non-Depreciable) Fixed Costs

$\$ 1,859,825$

ANNUAL COSTS

Levelized Capital (Depreciable)

\$ / Year

mills/kWh

Variable Cost (Benefit)

$\$ 108,313$

1922.58927

Fixed Cost (Benefit)

$\$ 954$

16.93280

Total

FINANCIAL RESULTS

Net Present Value

at the Discount Rate of

$15 \%$

$(\$ 1,337,262)$

Internal Rate of Return

Standard Calculation

ERR

Alternate Calculation

$10.00 \%$

If Standard Calculation and Alternate Calculation Are Not Equal or ERR Appears Activate IRR Calculation button

Payback (Years)

Greater than Evaly ation Period 


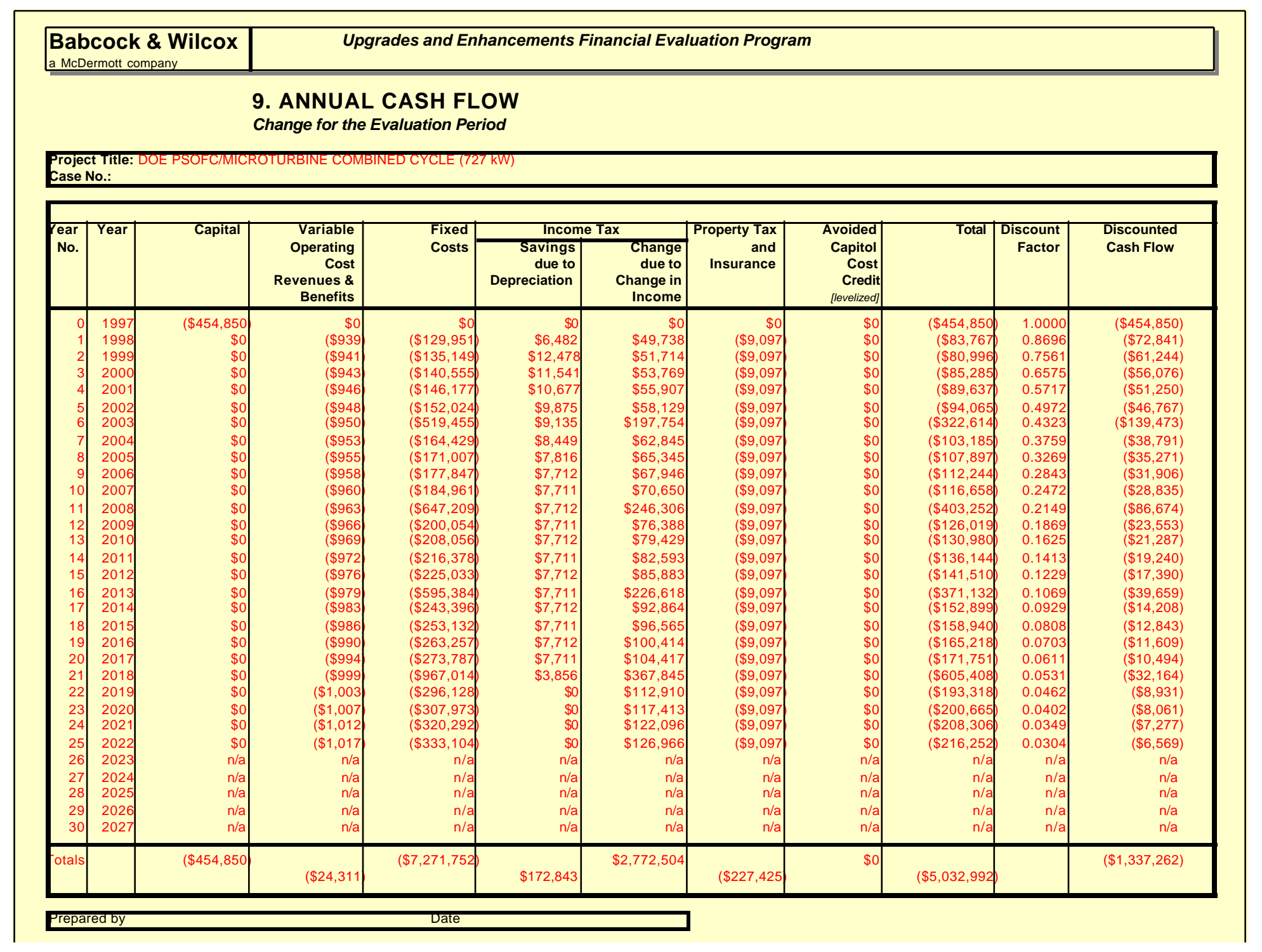




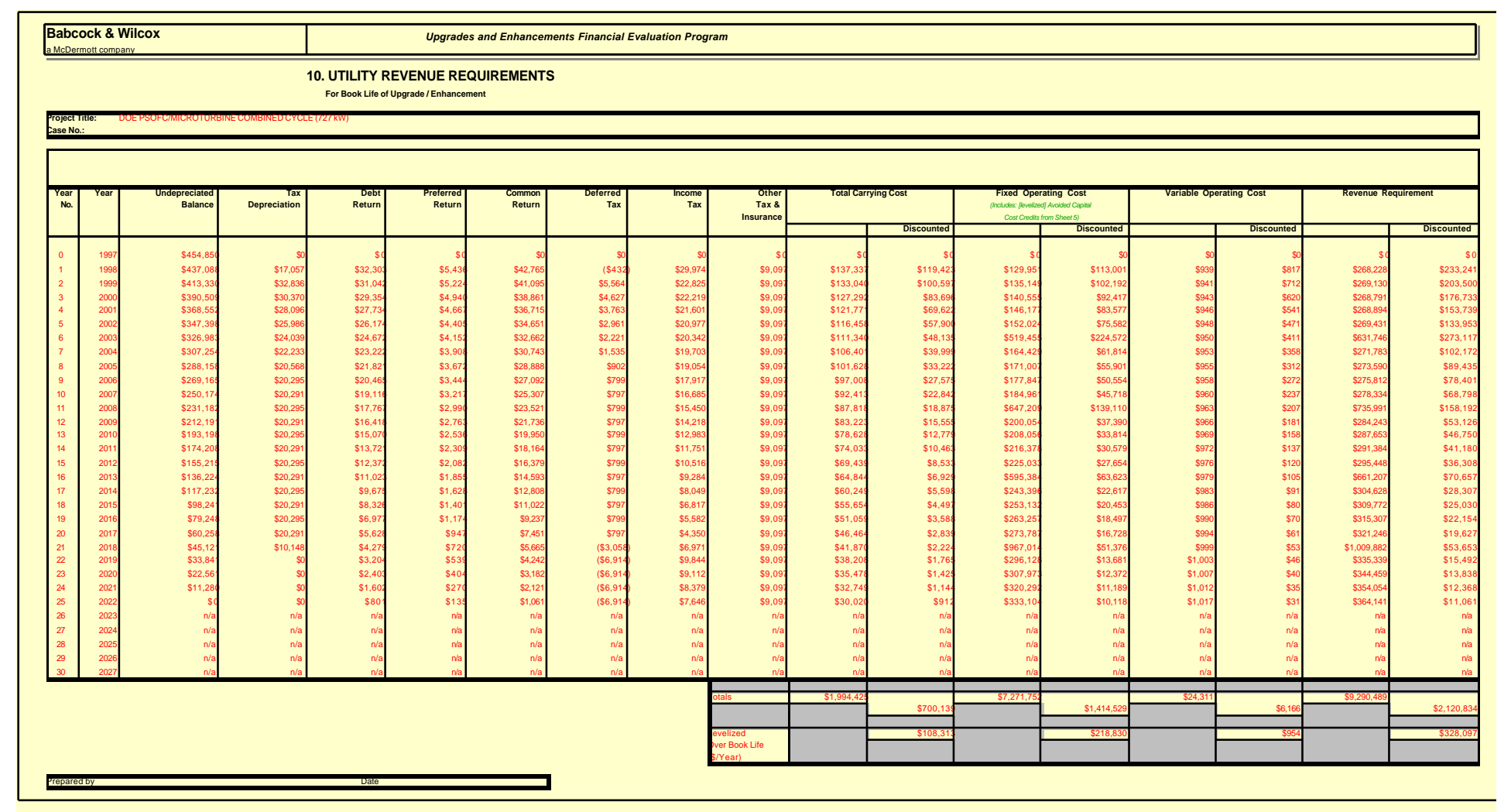

